\title{
Levels of Chemical Toxicants in Waterpipe Tobacco and Waterpipe Charcoal Solid Waste
}

\author{
Jason R. Hsieh (, Megan L. Mekoli, Ronald L. Edwards Jr.* \\ Office of Science, Center for Tobacco Products, U.S. Food and Drug Administration, Calverton, MD, USA \\ Email: ${ }^{\star}$ Ronald.Edwards@fda.hhs.gov
}

How to cite this paper: Hsieh, J.R., Mekoli, M.L. and Edwards Jr., R.L. (2021) Levels of Chemical Toxicants in Waterpipe Tobacco and Waterpipe Charcoal Solid Waste. Journal of Environmental Protection, 12, 913-938.

https://doi.org/10.4236/jep.2021.1211054

Received: October 13, 2021

Accepted: November 23, 2021

Published: November 26, 2021

Copyright ( 2021 by author(s) and Scientific Research Publishing Inc. This work is licensed under the Creative Commons Attribution International License (CC BY 4.0).

http://creativecommons.org/licenses/by/4.0/

\begin{abstract}
This work provides insights on waterpipe tobacco and waterpipe charcoal as potential sources of environmental toxicants. Selected harmful and potentially harmful constituents (HPHCs) from ten U.S. commercial waterpipe tobacco filler products (before and after electric heating) and five waterpipe charcoal products (before and after burning) were investigated. The differences in quantities of HPHCs between the evaluated products appear to be affected by raw material properties and/or the manufacturing processes involved in product production. Trace metal quantities in waterpipe tobacco and charcoal products were observed after heating or burning conditions compared to unheated or unburned conditions, which could impact the environment through the generation of toxic tobacco product waste. This study demonstrates that waterpipe tobacco and waterpipe charcoal contain substantial quantities of benzo[a]pyrene $(\mathrm{B}[\mathrm{a}] \mathrm{P})$ and trace metals (i.e., selenium, arsenic, cadmium, chromium, cobalt, lead, nickel) before use and that extensive and varied changes in trace metal quantities take place as a result of heating, and more studies are needed to estimate the magnitude of the environmental impact of waterpipe tobacco use.
\end{abstract}

\section{Keywords}

Harmful and Potentially Harmful Constituents, Charcoal, Waterpipe, Metals, Tobacco Product Waste

\section{Introduction}

The use of waterpipe (WP) tobacco (also known as hookah, maassel, narghile, argileh, shisha) and WP charcoal as a heating source has increasingly spread among youth and young adults worldwide [1] [2] [3] [4] [5]. WP tobacco 
smoking is often incorrectly perceived as less harmful, less addictive, and a safer alternative to combustible cigarette smoking [6]. The World Health Organization (WHO) estimated that a single session of WP smoking could release as much as 100 - 200 times the smoke volume of a single cigarette [7] [8]. Several studies have investigated the harmful and potentially harmful constituents (HPHCs) in WP tobacco smoke, such as polycyclic aromatic hydrocarbons (PAHs), carbon monoxide (CO), nicotine, and other toxicants (tar) produced from WP smoking [9] [10]. However, few studies have assessed the quantities of HPHCs remaining in WP tobacco and WP charcoal product wastes after use, or in WP tobacco separate from WP charcoal. The U.S. Food and Drug Administration (FDA) received authority to regulate the manufacturing, distribution, and marketing of tobacco products in the United States through the Family Smoking Prevention and Tobacco Control Act in 2009 [11]. FDA further extended its tobacco regulatory authorities to other tobacco products (Deeming Rule), including WP tobacco and WP charcoal, in 2016 [12]. This study will inform FDA's efforts to fulfill the National Environmental Policy Act (NEPA) which requires that U.S. federal agencies evaluate the environmental impacts of proposed actions such as reviewing applications for marketing authorization and developing product standards to improve public health.

A WP setup consists of a head, stem, gasket, base, release valve, hose, and mouthpiece (Figure 1(a)). For typical WP smoking, a mixture containing WP tobacco and other additives is placed in the head, covered with perforated aluminum foil, and indirectly heated using smoldering charcoal. The produced
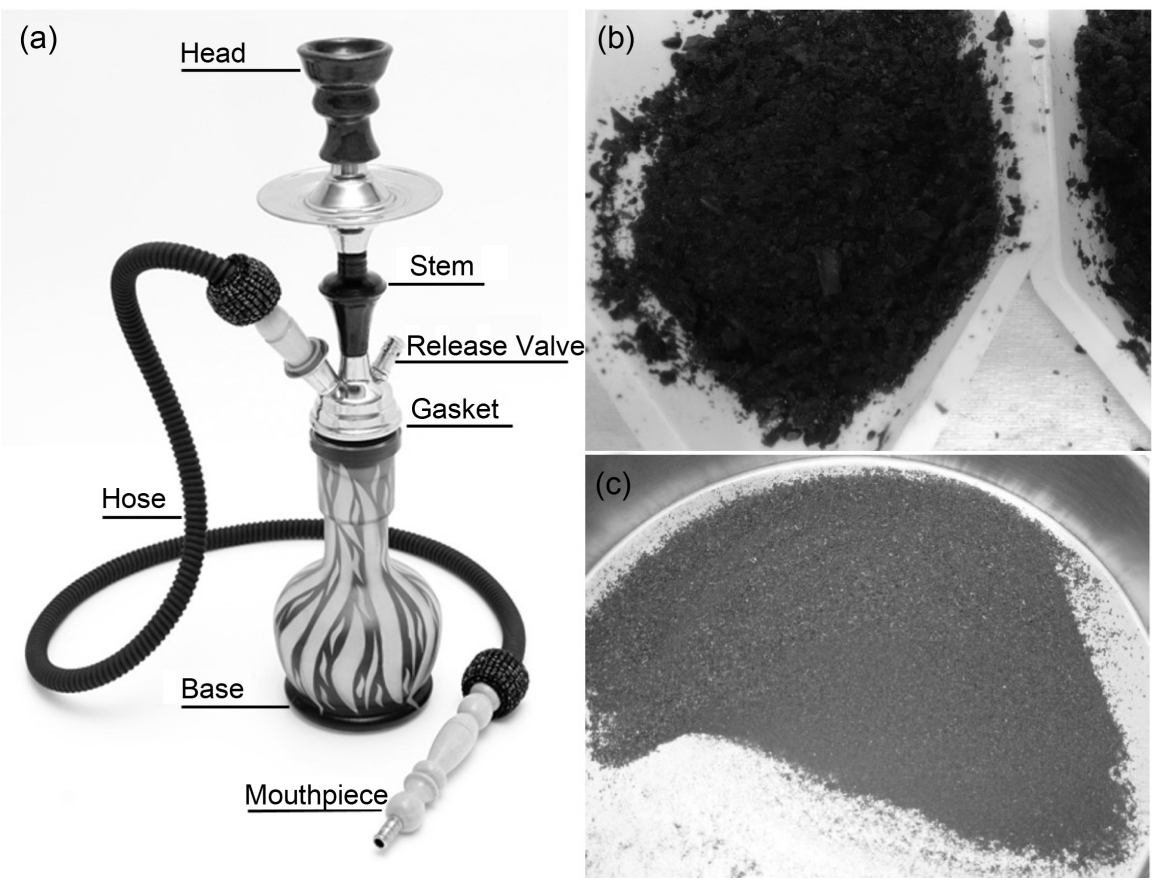

Figure 1. (a) Representative schematic diagram of a WP apparatus; (b) Representative product images of homogenized WP tobacco before heating; (c) Homogenized WP charcoal before burning. 
smoke passes through the base, which is partially filled with liquid, and then inhaled by the user through a hose (with mouthpiece) connected to the WP base [13]. Although water is often used to fill the base, it has been reported that additional flavors can be introduced by substituting the water with milk, wine, fruit juice, or energy drinks [14] [15]. Users often believe [16] that liquid "filtration" in the WP apparatus can efficiently remove excess HPHCs, such as toxic metals, produced from WP tobacco and WP charcoal. However, Al-Kazwini et al. determined that only about $3 \%$ of the total metal is removed from smoke through the water base of the WP apparatus [17].

Flavored WP tobacco is often used in WP smoking; flavored WP tobacco is a complex mixture [18] composed of approximately $30 \%$ tobacco and $70 \%$ nontobacco ingredients and may contain glycerin, molasses, honey, sugar, fruit pulp, other flavorings (e.g., mint, coconut, peach, cola, bubble gum, grape), and preservatives [19]. Aromatic smoke produced from flavored WP tobacco may be particularly appealing to youth [20]. Several studies have investigated human health diseases (e.g., lung disease, oral cancer) associated with WP smoking [21] [22] and exposure to high concentrations of heavy metals is known to cause adverse effects on humans [23]. Specifically, the tobacco plant is capable of trapping and accumulating heavy metals [24], including cadmium (Cd), zinc ( $\mathrm{Zn}$ ), copper $(\mathrm{Cu})$, iron $(\mathrm{Fe})$, and lead $(\mathrm{Pb})$, which are also commonly found in other tobacco products [25].

WP charcoal is used as a heating source in WP smoking and can be a potential source of contamination to the user and the environment. WP charcoal temperature can reach close to $450^{\circ} \mathrm{C}$ compared to $900^{\circ} \mathrm{C}$ in a burning cigarette [26]. Several studies have investigated the formation of HPHCs as a function of temperature in other tobacco products [27] [28] [29] [30]. WP charcoal is commonly produced from one of three sources: coconut husks, woods, or sugar cane stalks [31]. Heavy metals(e.g., zinc [Zn], Pb, Cd, Cu, nickel [Ni]) can be absorbed by the roots of plants [32], and the quantities of heavy metals in charcoal are dependent on the origin of the wood, type of wood, soil type and quality, and manufacturing processes [31]. Upon completion of a smoking session, WP tobacco and charcoal residues are often disposed into the environment, which adds to overall environmental contamination. Although the impact of environmental contamination of tobacco products such as cigarette butts has been investigated extensively [33] [34] [35] [36] [37], research on WP-associated wastes and their environmental impact is more limited. This work investigates WP tobacco residue and WP charcoal waste containing HPHCs such as metals (i.e., arsenic [As], Cd, cobalt [Co], chromium [Cr], Ni, Pb, selenium [Se]), PAHs (e.g., $\mathrm{B}[\mathrm{a}] \mathrm{P})$, carbonyls (e.g., acrolein, formaldehyde $[\mathrm{FA}]$ ), volatile organic compounds (VOCs) (e.g., benzene, isoprene), phenols (e.g., catechol, phenol), and tobacco-specific nitrosamines (TSNAs) (e.g., N-nitrosonornicotine [NNN], 4-(methylnitrosamino)-1-(3-pyridyl)-1-butanone [NNK]); these HPHCs are selected based on the commonality in WP tobacco and WP charcoal smoke, and 
they are on the FDA established list of 93 HPHCs in tobacco products and tobacco smoke.

\section{Materials and Methods}

\subsection{Preparation of Heated Tobacco and Burned Charcoal Samples}

A smoking machine (Hawktech FP2000 or Borgwaldt Shisha Smoker) operating under the Beirut puffing regimen [38] (puff volume: $0.530 \mathrm{~L}$, puff duration: 2.6 sec, interval between puffs: $17 \mathrm{sec}, 57$ min smoking session for total 171 puffs) was used to smoke a commercially available WP with one of ten selected brands of tobacco with different flavors. All WP tobacco and WP charcoal samples were purchased from online vendors and selected for their random flavors and additives and stored at room temperature. Ten WP tobacco brands with different flavors (chocolate and mint for T1, blueberry and mint for T2, orange and cherry for T3, passion fruit for T4, blueberry and mint for T5, blueberry and mint for $\mathrm{T} 6$, apple for T7, peach for T8, watermelon for T9, and orange for T10) and five WP charcoal brands with different materials and shapes (beech wood and disc shape for $\mathrm{C} 1$, coconut husks and cube shape for $\mathrm{C} 2$, instant and disc shape for $\mathrm{C} 3$, quicklight and disc shape for $\mathrm{C} 4$, natural and finger shape for $\mathrm{C} 5)$ were investigated ( $\mathrm{N}=7$ per brand). All WP tobacco brands were traditional tobacco except the T9 brand, which was a nicotine gel.

All WP tobacco and WP charcoal samples were weighed at the beginning of each machine smoking session. The smoking machine pulled air through a quantity of tobacco $(10 \mathrm{~g})$ in a head. The WP tobacco was then indirectly heated by an in-house electric heater, achieving similar temperatures as commercially available heaters $\left(360^{\circ} \mathrm{C}\right)$ [39] [40]. The resulting smoke was pulled down the stem (Figure 1(a)), bubbled through the water reservoir containing $18 \mathrm{M} \Omega$ deionized water in the base (enough water to cover $30 \mathrm{~mm}$ of the stem, approx. $1.5 \mathrm{~L}$ ), and passed through filters placed in-line at the junction between the base and the tubing to collect total particulate matter (TPM). For charcoal sample preparation, charcoal was placed on an electric burner (for lighting charcoal) for $100 \mathrm{sec}$ before placing it onto the ceramic WP head wrapped with perforated foil (18 holes). The smoking session was initiated and allowed to run undisturbed. At puff 99, the remaining charcoal (half of a charcoal) was lit and allowed to burn for an additional $100 \mathrm{sec}$ before being placed onto the aluminum foil at puff 105 . The smoking session was complete at puff 171 (57 min). Heated WP tobacco and burned WP charcoal were allowed to cool to room temperature, then transferred to a muffled glass container, and stirred until the mixture was homogenous. Homogenized samples were stored in sealed glass jars before testing. The consumed WP tobacco and WP charcoal masses were determined gravimetrically.

\subsection{Homogenization of Unheated Tobacco and Unburned Charcoal Samples}

All tobacco samples were aerated, cleaned of debris (removal of stems, twigs 
greater than $1 \mathrm{~cm}$ in length, whole leaves greater than $4 \mathrm{~cm}^{2}$, and stems) and then homogenized (approx. $100 \mathrm{~g}$ ) using gloved hands (nitrile). After homogenizing, each tobacco sample was added to a $40 \mathrm{oz}$ stainless steel carafe, chilled with dry ice, and blended (Waring model 33BL79, 120 volts/3amps) for three minutes or until particles with size approximately $4 \mathrm{~mm}$ were obtained visually (Figure 1(b)). After blending, any dry ice and excess moisture were allowed to evaporate to completion in a fume hood. All charcoal samples were placed into a plastic bag (9" x 12 " heavy-walled, zip-seal) and crushed with a rubber mallet inside of a fume hood. All crushed charcoal samples were sieved (No. 30 sieves, $600 \mu \mathrm{m}$ mesh) to yield a uniform particle size (Figure 1(c)). Charcoal samples intended for elemental analysis were treated differently from tobacco samples (no homogenization or sieving) to avoid possible contamination of the elements of interest from the stainless-steel carafe or metal sieve.

\subsection{GC-MS Analysis of VOC Compounds}

Purge-and-trap gas chromatography/mass spectrometry (GC-MS, [Agilent 6890 and 5973]) was used to identify and quantify isoprene and benzene in WP tobacco samples using established methods [41] [42] [43] [44]. VOCs in solid samples were introduced into the GC (Agilent 6890 GC with an Agilent 5973 Mass Selective Detector) by purge-and-trap techniques. An inert gas was bubbled through an aqueous phase to purge the VOC analytes from the aqueous phase into the gas phase. For low-level samples (samples with least preparation), laboratory reagent-grade water was used for the aqueous phase. Medium-level samples (samples requiring additional extractions or dilutions) were initially extracted in methanol $(10 \mathrm{~mL})$, and an aliquot $(\sim 3-4 \mathrm{~mL})$ was diluted in $20 \mathrm{~mL}$ of laboratory reagent water, creating the sample aqueous phase. The gas was swept through the sorbent trap (VOCARB 3000, Carbopack B/Carboxen 1000 \& 1001, $10 \mathrm{~cm}$ Carbopack B, $6 \mathrm{~cm}$ Carboxen 1000, $1 \mathrm{~cm}$ Carboxen 1001), where the volatile components were retained. After purging was complete, the sorbent trap was heated and backflushed with inert gas to desorb the components onto a non-polar fused silica capillary chromatographic column (Restek RTX-DHA 50 chromatographic column, $50 \mathrm{~m} \times 0.20 \mathrm{~mm}$ internal diameter fused silica capillary column with a $0.5 \mu \mathrm{m}$ bonded phase). The desorbed components were then separated via capillary GC and identified and quantified using electron ionization (positive and negative) mass spectrometry (MS) in the full-scan mode. Deuterated benzene, deuterated toluene, and deuterated ethylbenzene were used as internal standards, and 1,4-difluorobenzene, deuterated chlorobenzene, and deuterated 1,4-dichlorobenzene were used as surrogate samples.

\subsection{HPLC Analysis of Carbonyl Compounds}

FA and acrolein in WP tobacco samples (1 $\mathrm{g}$ of solid sample each) were extracted with $20 \mathrm{~mL}$ of extraction solution $(64.3 \mathrm{~mL}$ of $1.0 \mathrm{~N} \mathrm{NaOH}, 5.7 \mathrm{~mL}$ of glacial acetic acid, $930 \mathrm{~mL}$ of deionized water, at $\mathrm{pH} 4.9$ ). The sample extract was decanted through a glass fiber filter paper in a $200 \mathrm{~mL}$ glass jar, then $10 \mathrm{~mL}$ of 
filtered extract was diluted with $90 \mathrm{~mL}$ of deionized water, $4 \mathrm{~mL}$ of $1 \mathrm{M}$ concentrated citrate buffer $(80 \mathrm{~mL}$ of $1 \mathrm{M}$ citric acid and $20 \mathrm{~mL}$ of $1 \mathrm{M}$ sodium citrate, at $\mathrm{pH} 3)$, and $6 \mathrm{~mL}$ of 2,4-dinitrophenylhydrazine (DNPH) solution (70\% w/w in acetonitrile) in a $200 \mathrm{~mL}$ glass jar with a screw cap. The combined solution was shaken $(90 \mathrm{rpm})$ on an oscillating incubator at $40^{\circ} \mathrm{C}$ for 1 hour. A $10 \mathrm{~mL}$ of saturated $\mathrm{NaCl}$ solution was added into the combined solution and shaken well, and then the combined solution was transferred onto a C18 solid-phase extraction (SPE) cartridge (Thermo Scientific). A vacuum pump was used to ensure that all the solution was drawn through the cartridge at a rate of $3-5 \mathrm{~mL} / \mathrm{min}$. The solution was passed through the C18 SPE cartridge with $9 \mathrm{~mL}$ of acetonitrile. The eluent was collected and analyzed using high-performance liquid chromatography (HPLC, Shimadzu Nexera system with a CBM-20A controller, DGU-20A3R degassing unit, DGU-20A5R degassing unit, LC-30AD pump, SIL-30AC autosampler, CTO-30A column oven) with an ultraviolet detector (SPD-20AV) using established methods [45] [46] [47].

\subsection{GC-MS Analysis of $\mathrm{B}[\mathrm{a}] \mathrm{P}$ Compound}

$\mathrm{B}[\mathrm{a}] \mathrm{P}$ in unheated and heated WP tobacco, and unburned and burned WP charcoal samples ( $1 \mathrm{~g}$ of solid sample each), was extracted by sonication (at 30 or $50^{\circ} \mathrm{C}$ for 2 hours) using $15 \mathrm{~mL}$ of toluene. Each extract was spiked with deuterated perylene as an internal standard and passed through an SPE cartridge using $10 \mathrm{~mL}$ of hexane. Each eluent was concentrated to dryness using a nitrogen evaporator (Organomation N-evap Analytical Evaporator, model 111) at room temperature, and brought back up to $100 \mu \mathrm{L}$ with acetonitrile $(\mathrm{ACN})$, prior to analysis using GC-MS (Agilent 6890N GC with an Agilent 5975MS), operated in selected ion monitoring mode (SIM), using established methods [10] [48] [49] [50]. The quantitation ion $(\mathrm{m} / \mathrm{z})$ and confirmation ion $(\mathrm{m} / \mathrm{z})$ were 252 and 253 , respectively.

\subsection{LC-MS/MS Analysis of TSNA Compounds}

NNN and NNK in unheated and heated WP tobacco samples (1 g of solid sample each) were extracted using $40 \mathrm{~mL}$ of $100 \mathrm{mM}$ ammonium acetate. Deuterated form of $\mathrm{NNN}-\mathrm{d}_{4}$ and $\mathrm{NNK}-\mathrm{d}_{4}$ were added $(160 \mu \mathrm{L}$ of a $5 \mathrm{ng} / \mu \mathrm{L}$ solution into 40 $\mathrm{mL}$ extraction solvent) as internal standards, and the extract was mixed well using a rotary shaker for 1 hour at $250 \mathrm{rpm}$. One $\mathrm{mL}$ of each extract was filtered with a $0.45 \mu \mathrm{m}$ GHP (hydrophilic polypropylene membrane) syringe filter on a 5-mL BD (Becton Dickinson) syringe and added into autosampler vials, followed by analysis using LC-MS/MS (Waters ACQUITY HPLC and Waters Xevo TQ MS) in positive electrospray ion mode, multiple reaction monitoring (MRM) mode, and with an analytical column (Phenomenex Gemini C18, 5 $\mu$ 110A, $50 \times$ $2 \mathrm{~mm}$ ) [49] [51] [52]. A gradient consisting of $0.1 \%$ acetic acid in water (solvent A), and $0.1 \%$ acetic acid in methanol (solvent B) at a constant flow rate of 100 $\mu \mathrm{L} / \mathrm{min}$ was used. The solvent gradient program was as follows: $0 \mathrm{~min}, 40 \% \mathrm{~B}$; $0.5 \mathrm{~min}, 40 \% \mathrm{~B}$; $5.0 \mathrm{~min}, 65 \% \mathrm{~B} ; 5.5 \mathrm{~min}, 100 \% \mathrm{~B} ; 6.0 \mathrm{~min}, 100 \% \mathrm{~B} ; 6.1 \mathrm{~min}, 30 \%$ 
B; $8.0 \mathrm{~min}, 30 \% \mathrm{~B}$. The injection volume was $20 \mu \mathrm{L}$. The column temperature was maintained at $40^{\circ} \mathrm{C}$. MS/MS transitions $(\mathrm{m} / \mathrm{z})$ for NNN were as follows: $178 \rightarrow 148$ (quantitation); $178 \rightarrow 120$ (confirmation); $182 \rightarrow 152\left(\mathrm{NNN}^{-} \mathrm{d}_{4}\right.$ internal standard). MS/MS transitions (m/z) for NNK were as follows: $208 \rightarrow 122$ (quantitation); $208 \rightarrow 79$ (confirmation); $212 \rightarrow 126$ (NNK- $\mathrm{d}_{4}$ internal standard).

\subsection{LC-FLD Analysis of Phenolic Compounds}

Phenol and catechol in unheated and heated WP tobacco samples $(1 \mathrm{~g}$ of solid sample each) were extracted using $50 \mathrm{~mL}$ of $1 \%(\mathrm{v} / \mathrm{v})$ acetic acid in water and mixed using a shaker (New Brunswick Scientific Co., model G-3.3) for an hour. The liquid layer of extraction solution was decanted into a $50 \mathrm{~mL}$ polypropylene centrifuge tube and centrifuged for $2 \mathrm{~min}$ at $2000 \mathrm{rpm}$. After centrifugation, 1 $\mathrm{mL}$ of sample extract was filtered through a $0.45 \mu \mathrm{m}$ nylon syringe filter into an LC vial for analysis using liquid chromatography with a fluorescence detector (LC-FLD) [53]. Analytes of interest were separated using a column (Phenomenex; $150 \mathrm{~mm} \times 3.0 \mathrm{~mm}, 3 \mu \mathrm{m}$ particle size Devosil 3u RP-Aqueous C30 140A). A gradient consisting of $1.0 \%$ acetic acid in water (solvent $\mathrm{A}$ ) and $0.1 \%$ acetic acid in acetonitrile (solvent $\mathrm{B}$ ) at a constant flow rate of $0.55 \mathrm{~mL} / \mathrm{min}$ was used. The solvent gradient program was as follows: $0 \mathrm{~min}, 3 \% \mathrm{~B} ; 3 \mathrm{~min}, 3 \% \mathrm{~B} ; 5 \mathrm{~min}, 19 \%$ B; 15 min, 19\% B; 17 min, 85\% B; 19 min, 85\% B; 21 min, 3\% B; 24 min, 3\% B. The oven temperature was maintained at $40^{\circ} \mathrm{C}$, the injection volume used was 10 $\mu \mathrm{L}$, and the excitation and emission wavelengths used were $274 \mathrm{~nm}$ and $298 \mathrm{~nm}$, respectively.

\subsection{ICP-MS Analysis of Trace Metals}

Seven selected trace metals ( $\mathrm{As}, \mathrm{Cd}, \mathrm{Co}, \mathrm{Cr}, \mathrm{Ni}, \mathrm{Pb}$, and $\mathrm{Se}$ ) were measured in unheated and heated WP tobacco samples ( $0.1 \mathrm{~g}$ of solid sample each) and in unburned and burned WP charcoal (0.5 g of solid sample each). Each sample was placed in a clean, dry microwave digestion vessel with $10 \mathrm{~mL}$ of concentrated nitric acid. Microwave digestion was accomplished by ramping the temperature and digesting the samples (CEM Corporation Xpress); the samples were ramped to a temperature of $170^{\circ} \mathrm{C} \pm 5^{\circ} \mathrm{C}$ over $10 \mathrm{~min}$ and held at a constant temperature for 10 - $20 \mathrm{~min}$ ) [54]. After microwave digestion, samples were allowed to cool. The cooled sample extract was placed into a $50 \mathrm{~mL}$ conical vial and brought to a final volume of $50 \mathrm{~mL}$ using $2 \%$ aqueous nitric acid. A solution containing $100 \mu \mathrm{g} / \mathrm{L}$ of scandium (Sc), $50 \mu \mathrm{g} / \mathrm{L}$ of indium (In), $50 \mu \mathrm{g} / \mathrm{L}$ of terbium ( $\mathrm{Tb}$ ), and $50 \mu \mathrm{g} / \mathrm{L}$ of yttrium $(\mathrm{Y})$ in $1 \%$ nitric acid was used as an internal standard. All extract samples are analyzed using inductively coupled-plasma mass spectrometry (ICP-MS, Perkin Elmer Elan with a Dynamic Reaction Cell [DRC-e]) [54] [55].

\section{Results}

\subsection{HPHCsin WP Tobacco}

Table 1 and Table 2 show nine selected HPHCs measured in heated and unheated 
Table 1. Quantification of HPHCs in unheated WP tobacco solid waste.

\begin{tabular}{ccccccccccc}
\hline WP Tobacco Brands & ${ }^{a}$ Acrolein & ${ }^{a}$ Benzene & ${ }^{a}$ Isoprene & ${ }^{b}$ Catechol & ${ }^{b}$ Phenol & ${ }^{b}$ FA & ${ }^{c} B[a] P$ & ${ }^{c} N N K$ & ${ }^{c} N N N$ \\
\hline T1 Chocolate/Mint & BLOQ & BLOQ & BLOQ & $31.4 \pm 0.8$ & $1.9 \pm 0.1$ & $0.2 \pm 0.1$ & BLOQ & $4.7 \pm 0.5$ & BLOQ \\
T2 Blueberry/Mint & BLOQ & BLOQ & $8.3 \pm 0.4$ & $36.1 \pm 0.6$ & $1.2 \pm 0.2$ & $1.2 \pm 0.2$ & BLOQ & $9.0 \pm 1.8$ & $5.0 \pm 0.9$ \\
T3 Orange/Cherry & BLOQ & BLOQ & BLOQ & $50.5 \pm 0.5$ & $1.6 \pm 0.1$ & $2.0 \pm 0.9$ & BLOQ & $37.0 \pm 2.0$ & $26.6 \pm 1.9$ \\
T4 Passion Fruit & BLOQ & BLOQ & $22.5 \pm 0.5$ & $40.6 \pm 1.5$ & $5.6 \pm 0.4$ & $1.0 \pm 0.1$ & $1.5 \pm 0.3$ & $6.1 \pm 0.3$ & BLOQ \\
T5 Blueberry/Mint & BLOQ & BLOQ & BLOQ & $49.8 \pm 1.9$ & $3.4 \pm 0.2$ & $5.4 \pm 0.2$ & $1.9 \pm 0.2$ & $5.3 \pm 0.1$ & BLOQ \\
T6 Blueberry/Mint & BLOQ & BLOQ & BLOQ & $25.9 \pm 3.6$ & $1.7 \pm 0.7$ & $2.8 \pm 0.1$ & BLOQ & $5.9 \pm 0.5$ & $3.8 \pm 0.7$ \\
T7 Apple & BLOQ & BLOQ & BLOQ & $45.2 \pm 0.9$ & $9.1 \pm 0.1$ & $0.3 \pm 0.1$ & BLOQ & $38.3 \pm 1.5$ & $22.3 \pm 1.2$ \\
T8 Peach & BLOQ & BLOQ & BLOQ & $36.6 \pm 0.8$ & $5.5 \pm 0.2$ & $1.8 \pm 0.2$ & $1.1 \pm 0.3$ & $7.4 \pm 0.6$ & $2.7 \pm 0.5$ \\
T9 Watermelon & BLOQ & BLOQ & $10.5 \pm 0.5$ & BLOQ & $0.6 \pm 0.1$ & $2.8 \pm 0.2$ & BLOQ & BLOQ & BLOQ \\
T10 Orange & BLOQ & BLOQ & BLOQ & $21.1 \pm 1.1$ & $2.3 \pm 0.2$ & $1.6 \pm 0.6$ & BLOQ & $298.3 \pm 5.3$ & $211.4 \pm 4.1$ \\
\hline
\end{tabular}

Note. ${ }^{a}$ Acrolein, Benzene, Isoprene values are presented in $\mathrm{ng} / \mathrm{g}$ (mean \pm s.d., $\mathrm{N}=7$ per brand). BLOQ means below the limit of quantification, LOQ for acrolein, benzene, and isopresent are $40 \mathrm{ng} / \mathrm{g}, 56 \mathrm{ng} / \mathrm{g}$, and $8 \mathrm{ng} / \mathrm{g}$, respectively. ${ }^{\mathrm{b}} \mathrm{Catechol}$, Phenol, FA values are presented in $\mu \mathrm{g} / \mathrm{g}$ (mean \pm s.d., $\mathrm{N}=7$ per brand). BLOQ means below the limit of quantification, LOQ for catechol, phenol, and FA are $0.7 \mu \mathrm{g} / \mathrm{g}, 0.1 \mu \mathrm{g} / \mathrm{g}$, and $0.03 \mu \mathrm{g} / \mathrm{g}$, respectively. ${ }^{\mathrm{c}} \mathrm{B}[\mathrm{a}] \mathrm{P}, \mathrm{NNK}, \mathrm{NNN}$ values are presented in ng/g (mean \pm s.d., $\mathrm{N}$ $=7$ per brand). BLOQ means below the limit of quantification, LOQ for B[a]P, NNK, and NNN are $0.5 \mathrm{ng} / \mathrm{g}, 5 \mathrm{ng} / \mathrm{g}$, and $5 \mathrm{ng} / \mathrm{g}$, respectively.

Table 2. Quantification of HPHCs in heated WP tobacco solid waste.

\begin{tabular}{|c|c|c|c|c|c|c|c|c|c|}
\hline $\begin{array}{c}\text { WP Tobacco } \\
\text { Brands }\end{array}$ & ${ }^{\mathrm{a}}$ Acrolein & ${ }^{\mathrm{a} B e n z e n e}$ & ${ }^{a}$ Isoprene & ${ }^{\mathrm{b}}$ Catechol & ${ }^{\mathrm{b}}$ Phenol & ${ }^{b} \mathrm{FA}$ & ${ }^{\mathrm{c}} \mathrm{B}[\mathrm{a}] \mathrm{P}$ & ${ }^{c} \mathrm{NNK}$ & ${ }^{c} \mathrm{NNN}$ \\
\hline $\begin{array}{c}\text { T1 } \\
\text { Chocolate/Mint }\end{array}$ & $75.7 \pm 9.3$ & BLOQ & BLOQ & $40.9 \pm 4.6$ & $11.5 \pm 1.4$ & $4.4 \pm 0.7$ & $1.2 \pm 0.1$ & $6.5 \pm 0.5$ & BLOQ \\
\hline $\begin{array}{c}\mathrm{T} 2 \\
\text { Blueberry/Mint }\end{array}$ & $53.7 \pm 7.9$ & BLOQ & BLOQ & $52.8 \pm 12.2$ & $8.1 \pm 1.1$ & $4.1 \pm 1.0$ & $1.3 \pm 0.2$ & $10.4 \pm 0.9$ & BLOQ \\
\hline $\begin{array}{c}\mathrm{T} 3 \\
\text { Orange/Cherry }\end{array}$ & $53.9 \pm 16.2$ & BLOQ & BLOQ & $43.2 \pm 3.0$ & $7.5 \pm 0.7$ & $2.6 \pm 0.3$ & BLOQ & $45.7 \pm 6.7$ & $17.7 \pm 1.8$ \\
\hline T4 Passion Fruit & $65.6 \pm 14.4$ & $73.6 \pm 30.1$ & BLOQ & $44.8 \pm 3.6$ & $6.9 \pm 0.3$ & $3.5 \pm 0.5$ & $2.2 \pm 0.2$ & $7.7 \pm 0.7$ & BLOQ \\
\hline $\begin{array}{c}\text { T5 } \\
\text { Blueberry/Mint }\end{array}$ & $65.6 \pm 10.6$ & $95.9 \pm 22.4$ & BLOQ & $45.7 \pm 8.8$ & $13.0 \pm 1.3$ & $3.4 \pm 0.3$ & $1.5 \pm 0.1$ & $7.2 \pm 1.3$ & BLOQ \\
\hline $\begin{array}{c}\text { T6 } \\
\text { Blueberry/Mint }\end{array}$ & $43.0 \pm 1.0$ & $96.6 \pm 30.6$ & BLOQ & $56.8 \pm 5.5$ & $7.5 \pm 1.3$ & $2.9 \pm 0.2$ & $1.3 \pm 0.2$ & $12.9 \pm 1.9$ & BLOQ \\
\hline T7 Apple & $51.5 \pm 2.0$ & $73.6 \pm 22.2$ & BLOQ & $43.7 \pm 6.5$ & $15.9 \pm 2.1$ & $2.9 \pm 0.5$ & BLOQ & $44.4 \pm 4.1$ & $26.6 \pm 3.8$ \\
\hline T8 Peach & $43.8 \pm 3.2$ & BLOQ & BLOQ & $49.8 \pm 9.8$ & $8.2 \pm 0.5$ & $4.0 \pm 0.6$ & $1.6 \pm 0.1$ & $15.0 \pm 2.6$ & BLOQ \\
\hline T9 Watermelon & BLOQ & BLOQ & BLOQ & BLOQ & $1.3 \pm 0.1$ & $2.9 \pm 1.4$ & BLOQ & BLOQ & BLOQ \\
\hline T10 Orange & BLOQ & $134.2 \pm 19.6$ & BLOQ & $48.3 \pm 7.9$ & $6.0 \pm 0.6$ & $3.0 \pm 0.3$ & BLOQ & $291.8 \pm 35.5$ & $141.4 \pm 30.2$ \\
\hline
\end{tabular}

Note. ${ }^{a}$ Acrolein, Benzene, Isoprene values are presented in $\mathrm{ng} / \mathrm{g}$ (mean \pm s.d., $\mathrm{N}=7$ per brand). BLOQ means below the limit of quantification, LOQ for acrolein, benzene, and isopresent are $40 \mathrm{ng} / \mathrm{g}, 56 \mathrm{ng} / \mathrm{g}$, and $8 \mathrm{ng} / \mathrm{g}$, respectively. ${ }^{\mathrm{b}}$ Catechol, Phenol, FA values are presented in $\mu \mathrm{g} / \mathrm{g}$ (mean \pm s.d., $\mathrm{N}=7$ per brand). BLOQ means below the limit of quantification, LOQ for catechol, phenol, and FA are $0.7 \mu \mathrm{g} / \mathrm{g}, 0.1 \mu \mathrm{g} / \mathrm{g}$, and $0.03 \mu \mathrm{g} / \mathrm{g}$, respectively. ${ }^{\mathrm{c}} \mathrm{B}[\mathrm{a}] \mathrm{P}, \mathrm{NNK}, \mathrm{NNN}$ values are presented in ng/g (mean $\pm \mathrm{s} . \mathrm{d} ., \mathrm{N}$ = 7 per brand). BLOQ means below the limit of quantification, LOQ for B[a]P, NNK, and NNN are $0.5 \mathrm{ng} / \mathrm{g}, 5 \mathrm{ng} / \mathrm{g}$, and $5 \mathrm{ng} / \mathrm{g}$, respectively. 
WP tobacco (i.e., acrolein, benzene, isoprene, catechol, phenol, FA, B[a]P, NNK, and NNN). All WP tobacco analyses included a blank (no solid matrix) and a control sample ( $1 \mathrm{~g}$ of sand as a solid matrix). All HPHCs quantities were corrected to account for solvent blanks. Benzene was not detected above the limit of quantification (LOQ) (56 ng/g) in all ten brands of unheated WP tobacco and five of the ten brands of heated WP tobacco. The remaining five brands of heated WP tobacco contained benzene ranging from $73.6 \pm 22.2$ to $134.2 \pm 19.6$ ng/g. Although all ten brands of heated WP tobacco did not contain isoprene above the LOQ (8 ng/g), Brands T2 (blueberry and mint), T4 (passion fruit), and T9 (watermelon) of unheated WP tobacco contained isoprene at levels ranging from $8.3 \pm 0.4 \mathrm{ng} / \mathrm{g}$ to $22.5 \pm 0.5 \mathrm{ng} / \mathrm{g}$. Acrolein was quantifiable in all heated WP tobacco products $(43.0 \pm 1.0$ to $75.7 \pm 9.3 \mathrm{ng} / \mathrm{g})$ except for brands T9 (watermelon) and T10 (orange), while the levels were below the LOQ (40 ng/g) in all brands of unheated WP tobacco. FA levels in heated and unheated WP tobacco ranged from $2.6 \pm 0.3 \mu \mathrm{g} / \mathrm{g}$ to $4.4 \pm 0.7 \mu \mathrm{g} / \mathrm{g}$ and $0.2 \pm 0.1$ to $5.4 \pm 0.2 \mu \mathrm{g} / \mathrm{g}$, respectively.

The concentrations of $\mathrm{B}[\mathrm{a}] \mathrm{P}$ in unheated $\mathrm{WP}$ tobacco products ranged from below the LOQ $(0.5 \mathrm{ng} / \mathrm{g})$ to $1.9 \pm 0.2 \mathrm{ng} / \mathrm{g}$ across the ten brands tested. $\mathrm{B}[\mathrm{a}] \mathrm{P}$ is at or below the LOQ for seven WP tobacco brands (T1 [chocolate and mint], T2 [blueberry and mint], T3 [orange and cherry], T6 [blueberry mint], T7 [apple], T9 [watermelon], and T10 [orange]). B[a]P quantities in heated WP products were similar to those found in unheated products and ranged from LOQ (0.5 $\mathrm{ng} / \mathrm{g}$ ) to $2.2 \pm 0.2 \mathrm{ng} / \mathrm{g}$. B[a]P was below the LOQ in $4 \mathrm{WP}$ tobacco brands (T3 [orange and cherry], T7 [apple], T9 [watermelon], and T10 [orange]).

The quantities of NNN and NNK in unheated WP tobacco ranged from $2.7 \pm$ 0.5 to $211.4 \pm 4.1 \mathrm{ng} / \mathrm{g}$ and from $4.7 \pm 0.5$ to $298.3 \pm 5.3 \mathrm{ng} / \mathrm{g}$, respectively. Most unheated WP tobacco brands contained less than $50 \mathrm{ng} / \mathrm{g}$ for $\mathrm{NNN}$ and NNK except for the T9 (watermelon) brand. T9 brand is a nicotine gel that lacks tobacco leaves and necessary microbes to convert nicotine into NNN and NNK [56]. Therefore, no TSNA was detected above the LOQ of $5 \mathrm{ng} / \mathrm{g}$ in the T9 brand. The quantities of NNN and NNK in heated WP tobacco were comparable to those for unheated WP tobacco, which ranged from $17.7 \pm 1.8$ to $141.4 \pm 30.2$ $\mathrm{ng} / \mathrm{g}$ for NNN and $6.5 \pm 0.5$ to $291.8 \pm 35.5 \mathrm{ng} / \mathrm{g}$ for NNK. Neither NNN nor NNK was in the T9 brand, and NNN was not detected in six other WP tobacco brands (T1 [chocolate and mint], T2 [blueberry and mint], T4 [passion fruit], T5 [blueberry and mint], T6 [blueberry and mint], and T8 [peach]).

Catechol quantities in unheated and heated WP tobacco products ranged from $21.1 \pm 1.1$ to $50.5 \pm 0.5 \mu \mathrm{g} / \mathrm{g}$ and from $40.9 \pm 4.6$ to $56.8 \pm 5.5 \mu \mathrm{g} / \mathrm{g}$, respectively, except for the T9 brand, where catechol was below the LOQ $(0.7 \mu \mathrm{g} / \mathrm{g})$ in both unheated and heated WP tobacco products. Furthermore, phenol quantities in unheated and heated WP tobacco products ranged from $0.6 \pm 0.1$ to $9.1 \pm 0.1$ $\mu \mathrm{g} / \mathrm{g}$ and from $1.3 \pm 0.1$ to $15.9 \pm 2.1 \mu \mathrm{g} / \mathrm{g}$, respectively.

Supplementary Table S1 shows the recovered WP tobacco, and WP charcoal 
percentages ranged from $26.1 \% \pm 4.3 \%$ to $63.5 \% \pm 7.5 \%$ and from $58.2 \% \pm 3.1 \%$ to $75.7 \% \pm 1.0 \%$, respectively. The $\mathrm{T} 9$ tobacco sample had the lowest recovery rate because it was a gel product; the sample was wet at the start of the experiment, but it dried out quickly afterward. It appeared that all the WP charcoal samples with a disc shape had a higher recovery rate than charcoal samples with a cube or finger shape. Unheated WP tobacco samples had an average $\mathrm{pH}$ of $4.76 \pm$ 0.01 , while the heated WP tobacco samples had an average $\mathrm{pH}$ of $5.33 \pm 0.13$ (Supplementary Methods). Nicotine was detected above or close to the LOQ (0.5 $\mathrm{ng} / \mathrm{g}$ ) in all WP tobacco brands except the T9 brand (Supplementary Methods and Table S2). Total nicotine quantities in unheated and heated WP tobacco ranged from $0.7 \pm 0.0$ to $3.1 \pm 0.0 \mathrm{mg} / \mathrm{g}$ and from $0.3 \pm 0.1$ to $1.0 \pm 0.4 \mathrm{mg} / \mathrm{g}$, respectively.

Trace metal As increased 33\% - 127\% in all heated compared to unheated WP tobacco products except for brands T4 (passion fruit) and T5 (blueberry mint), which were below the LOQ $(0.1 \mu \mathrm{g} / \mathrm{L})$. There were $78 \%-198 \%$ and $14 \%-203 \%$ increases, respectively, in $\mathrm{Cd}$ and $\mathrm{Cr}$ quantities observed in heated WP tobacco products compared to unheated products in all brands except T4 (passion fruit) and T9 (watermelon). Cd was not detected in the T9 (watermelon) brand, and the quantity of $\mathrm{Cr}$ was $23 \%$ lower in the heated product for the T4 (passion fruit) brand. Co was detected in all heated WP tobacco products, and a $91 \%-168 \%$ increase of Co was measured in the heated products of T5 (blueberry and mint), T7 (apple), and T10 (orange) compared to the unheated products. Although Co was detected in all heated products except T9 (watermelon) brand, the quantities were below the LOQ $(0.1 \mu \mathrm{g} / \mathrm{L})$ in most unheated products, and therefore the $\%$ increase can only be determined for brands T5 (blueberry and mint, 112\%), T7 (apple, 168\%), and $\mathrm{T} 10$ (orange, 91\%). Increases in $\mathrm{Pb}$ and $\mathrm{Ni}$ quantities of $59 \%-518 \%$ and $47 \%-117 \%$, respectively, in heated WP tobacco products compared to unheated WP products were found in all WP tobacco brands except T9 (watermelon). Furthermore, a 37\% - 93\% increase in Se quantities in heated WP tobacco products compared to unheated WP products was only observed in T3 (orange and cherry) and T10 (orange) brands.

\subsection{Humectants in WP Tobacco}

Supplementary Table S3 shows the quantities of ethylene glycol, glycerol, and propylene glycerol in unheated WP tobacco ranged from below the LOQ (5 $\mu \mathrm{g} / \mathrm{g}$ ) to $1.5 \pm 0.1 \mathrm{mg} / \mathrm{g}$, from $211.1 \pm 19.2$ to $720.3 \pm 5.7 \mathrm{mg} / \mathrm{g}$, and from below the LOQ $(4 \mu \mathrm{g} / \mathrm{g})$ to $87.4 \pm 2.9 \mathrm{mg} / \mathrm{g}$, respectively. Ethylene glycol was below the LOQ for 4 WP tobacco brands (T1 [chocolate and mint], T8 [peach], T9 [watermelon], and T10 [orange]), and propylene glycol was below the LOQ for the T9 (watermelon) brand only (Supplementary Methods).

\subsection{HPHCs in WPC Harcoal}

Trace metals and $\mathrm{B}[\mathrm{a}] \mathrm{P}$ were investigated in the $\mathrm{WP}$ charcoal samples. $\mathrm{B}[\mathrm{a}] \mathrm{P}$ was 
found in all unburned WP charcoal products and ranged from $5.3 \pm 0.6$ to $95.0 \pm$ $8.0 \mathrm{ng} / \mathrm{g}$. B[a]P was not detected in any of the burned charcoal products. As quantities in unburned and burned charcoal products ranged from 91 to 3147 ng/g and from 129 to $7779 \mathrm{ng} / \mathrm{g}$, respectively. A 42\% - 147\% increase in As quantities were found in all burned WP charcoal samples compared to the corresponding unburned WP charcoal samples except for brand C1 (beech wood, disc shape), which remained unchanged. Cd was only found in unburned and burned WP charcoal samples in brands C3 (instant and disc shape, 7\% decrease) and C5 (natural and finger shape, 5\% decrease). Increases in Cr (50\%-180\%), $\mathrm{Co}(45 \%$ - 246\%), $\mathrm{Pb}(20 \%-197 \%)$, and $\mathrm{Ni}(68 \%$ - 202\%) quantities of burned charcoal samples compared to the corresponding unburned samples were found in all WP charcoal brands. Increases in Se (58\% - 105\%) quantities were found in the burned samples for brands C4 (quicklight, disc shape) and C5 (natural and finger shape) compared to the unburned WP samples.

\section{Discussion}

This study investigated the impact and possible toxic risks to the environment of disposing of used WP tobacco and burned WP charcoal products by quantifying selected toxic chemical constituents in tobacco and charcoal before and after consumption. WP may be perceived as less harmful than cigarettes due to WP tobacco's fruit flavors, sugary taste, and the belief that the smoke is filtered by the water. These factors may contribute to their appeal to young adults [2] [19]. Although the environmental impact of cigarette use is well documented [34] [57] [58], less is known about the environmental impact of WP use. This work does not focus on the HPHCs released in the smoke from WP tobacco products as this has been previously investigated [18] [39] [59].

In this work, we evaluated a series of WP tobacco products with different flavors (e.g., chocolate, mint, blueberry, orange, cherry, passion fruit, apple, peach, watermelon) as well as WP charcoal products with different materials (e.g., beech wood, coconut husks, instant, quicklight, natural) and shapes (e.g., disc, cube, finger), and quantified HPHCs present in these products pre- and post-consumption. For data analysis purposes, it would be useful to have a commercially available tobacco product that contains nicotine but does not have a traditional tobacco matrix for comparison because uptake of heavy metals by tobacco plant roots has been demonstrated [32]. To probe this tobacco matrix difference, we selected a nicotine gel for this investigation because it utilizes water-soluble polymeric materials for rapid nicotine release. We included a nicotine gel (Brand T9, watermelon flavor) as one of the ten tobacco products to evaluate and examine selected HPHCs and trace metals in the absence of tobacco leaves.

Table 1 and Table 2 show the yields of selected HPHCs in WP tobacco products under unheated (pre-consumption) and heated (post-consumption) conditions. Under ambient conditions, the quantification of acrolein, benzene, and isoprene in tobacco products has been a challenge due to the nature of their low 
boiling points $\left(53^{\circ} \mathrm{C}, 81^{\circ} \mathrm{C}\right.$, and $34^{\circ} \mathrm{C}$, respectively). This was particularly troublesome for tobacco products stored in non-sealed packaging containers, extraction efficiency with different organic solvents, and experiments conducted under a pressurized and ventilated environment.

The concentrations of acrolein and benzene ranged from $43.0 \pm 1.0 \mathrm{ng} / \mathrm{g}$ to $75.7 \pm 9.3 \mathrm{ng} / \mathrm{g}$ and $73.6 \pm 30.1$ to $134.2 \pm 19.6 \mathrm{ng} / \mathrm{g}$, respectively, in the heated tobacco samples. However, the concentrations of these analytes were found to be below LOQ in all the unheated tobacco samples. This suggests that both acrolein and benzene were primarily produced only during the consumption of tobacco samples, and a fraction of the overall quantities remained in the WP tobacco sample. Acrolein has been shown [60] to form from heating sugars; therefore, we expected to see acrolein in all WP tobacco samples after heating. However, acrolein quantities were below the LOQ in heated T9 (watermelon) and T10 (orange) tobacco samples; T9 was a gel, and the gel matrix may interfere with the heating process or contain less sugar content than other WP tobacco samples. Due to the relatively high volatility of carbonyl groups and hydrocarbons, it is reasonable to expect that acrolein and benzene may not remain in the heated WP tobacco. Interestingly, for unheated WP tobacco, the isoprene concentrations in seven of ten brands were below LOQ $(8 \mathrm{ng} / \mathrm{g}$ ), while three brands (T2 [blueberry and mint], T4 [passion fruit], and T9 [watermelon]) had levels ranging from 8.3 to $22.5 \mathrm{ng} / \mathrm{g}$. However, for heated WP tobacco, the levels of isoprene in all ten brands were below LOQ. The observed low yields of isoprene may be due to its low boiling point (high volatility), and most of the isoprene produced during heating was transferred to the smoke phase.

We also observed low concentrations of catechol, phenol, FA, and $\mathrm{B}[\mathrm{a}] \mathrm{P}$ in the WP tobacco before and after heating, which may suggest that these HPHCs, which are typically produced during the consumption of WP tobacco, are readily transferred to the smoke phase, and their concentrations are minor in the consumed WP tobacco. Potential random errors may have contributed to uncertainties of measured results (e.g., FA), including heating temperature and heating behavior. Large uncertainties from repeated runsin waterpipe tobacco products have been observed by others [61]. Some of these HPHCs have been documented to have an adverse effect on aquatic biota and the environment [62] [63] [64].

The concentrations of TSNAs, such as NNN and NNK, remained consistent pre- and post-consumption. The potential environmental risks caused by TSNAs in the aquatic environment are still limited [65] [66]. We observed limited HPHCs in the consumed WP tobacco from brand T9 (i.e., isoprene, phenol, FA). It should be noted that brand T9 (watermelon) is a nicotine-containing gel and not a traditional WP tobacco product; therefore, no tobacco-derived HPHCs are expected.

We quantified humectants such as ethylene glycol, glycerol, and propylene glycerol in unheated WP tobacco products (Supplementary Table S3), and the 
results are comparable to what is reported in the literature [67] for other tobacco products except for glycerol (mean of ten brands, $371 \pm 140 \mathrm{mg} / \mathrm{g}$ ). However, higher levels of glycerol in WP tobacco are not unexpected as it makes it easier for manufacturers to minimize the harshness of the WP tobacco for use by the consumer. Furthermore, Schubert et al. demonstrated that an increase in the humectant levels in unburned tobacco lowers the temperature in the WP head during a smoking session, thereby decreasing carbonyl levels in the smoke produced [68].

Although brand T9 (watermelon) is advertised and labeled as a nicotine-containing gel, the nicotine content of the gel was evaluated for confirmation, and nicotine was not detected in either heated or unheated samples. It is possible that gel manufacturing precluded the presence of nicotine, or the nicotine degraded over time, given the nature of the hydrogel [69]. Using various extraction and analysis methods [70], including basic conditions $(\mathrm{pH}>7$ ) with $2 \mathrm{~N} \mathrm{NaOH}$, resulted in detecting trace nicotine levels in the T9 (watermelon) brand of heated WP tobacco. However, these nicotine levels were an order of magnitude below the LOQ $(5 \mathrm{ng} / \mathrm{g})$ and thus could not be reliably quantified.

The $\mathrm{pH}$ of a tobacco product is known to affect the amount of unprotonated nicotine (the more readily absorbed form) [71] and influence TSNA formation [72]. An increase in $\mathrm{pH}$ in the WP tobacco product after heating was observed in all brands (Supplementary Table S2). This increase in alkalinity could lower metal ion solubility [73] [74] and cause metal ions to precipitate, accumulate, and remain in the tobacco products over time. The concentration of trace metals as a function of WP tobacco brands before and after heating is shown in Figure 2. Heavy metals are known to impact environmental health negatively [75]. All metals except for $\mathrm{Cr}$ were shown to increase in concentration in the remaining tobacco after heating. Increases in metal concentration after product heating may be a result of lower total tobacco mass. Interestingly, $\mathrm{Cr}$ is the only trace metal found above the LOQ for both unheated and heated conditions for brand T9; this is likely due to the absence of tobacco leaves that often carry heavy metal [24]. The T8 brand contained the most As, resulting in a $127 \%$ increase from $85 \pm$ $6 \mathrm{ng} / \mathrm{g}$ before heating to $192 \pm 25 \mathrm{ng} / \mathrm{g}$ after heating.

It was difficult to accurately extract volatile HPHCs from WP charcoal samples because activated charcoal acts like a sponge and can readily soak up organic compounds. Therefore, only inorganic trace metals and $\mathrm{B}[\mathrm{a}] \mathrm{P}$ are reported in this study. Figure 3 shows the overall trace metals and B[a]P levels in all WP charcoal brands under unburned and burned conditions. Interestingly, the charcoal sample profile follows the same trend as WP tobacco samples in Figure 2 (increasing metal concentration upon heating). For brands C3 (instant, disc shape), C4 (quicklight, disc shape), and C5 (natural, disc shape), the concentrations of trace metals increased by $52 \%-147 \%$ (As), $79 \%-180 \%(\mathrm{Cr}), 130 \%$ $201 \%(\mathrm{Ni})$, and $58 \%-105 \%(\mathrm{Se})$ in the burned sample, but the concentrations remained the same in brands $\mathrm{C} 1$ (beech wood, disc shape) and C2 (coconut 


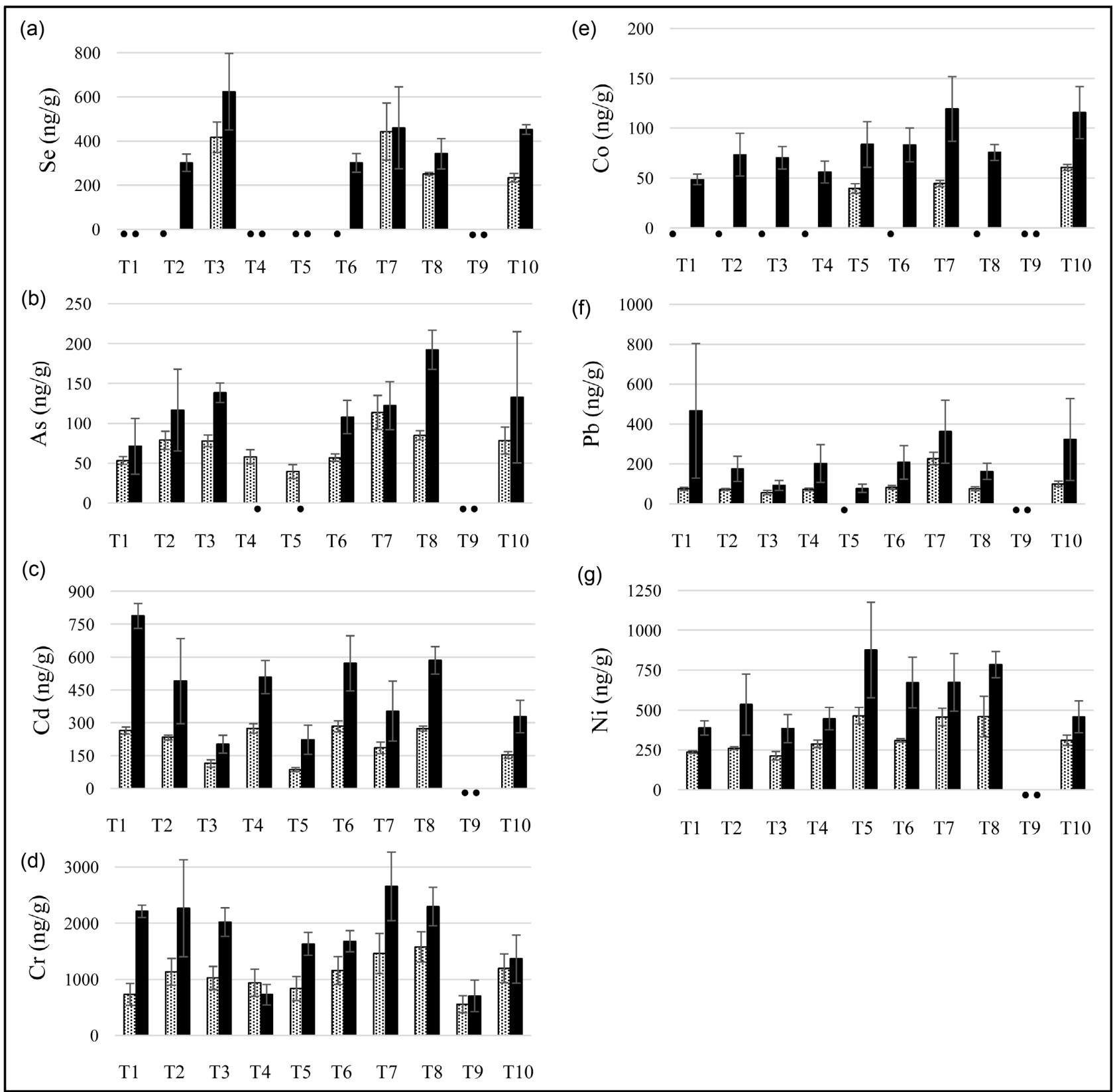

Figure 2. Comparison of trace metals in unheated (gray bars) and heated (black bars) WP tobacco solid waste. $(\bullet)$ meansbelow the limit of quantification. LOQ for Se $(0.5 \mu \mathrm{g} / \mathrm{L})$; As $(0.1 \mu \mathrm{g} / \mathrm{L})$, Cd $(0.1 \mu \mathrm{g} / \mathrm{L}), \mathrm{Cr}(0.5 \mu \mathrm{g} / \mathrm{L})$, Co $(0.1 \mu \mathrm{g} / \mathrm{L}), \mathrm{Pb}(0.1 \mu \mathrm{g} / \mathrm{L}), \mathrm{Ni}(0.1$ $\mu \mathrm{g} / \mathrm{L})$. Error bars indicate standard deviations.

husks, cube shape). This finding is interesting because consumers consider that WP charcoal made from coconut and natural woods to be less harmful than synthetic WP charcoals due to limited additives being added to the product [76]. This result may have occurred because the metal concentrations were relatively low at or below the LOQ. Since it can be assumed that the moisture content of WP charcoal is relatively low, humectants are not typically added to WP charcoal products. Therefore, the increase of trace metal quantities is likely due to something other than $\mathrm{pH}$ changes. 


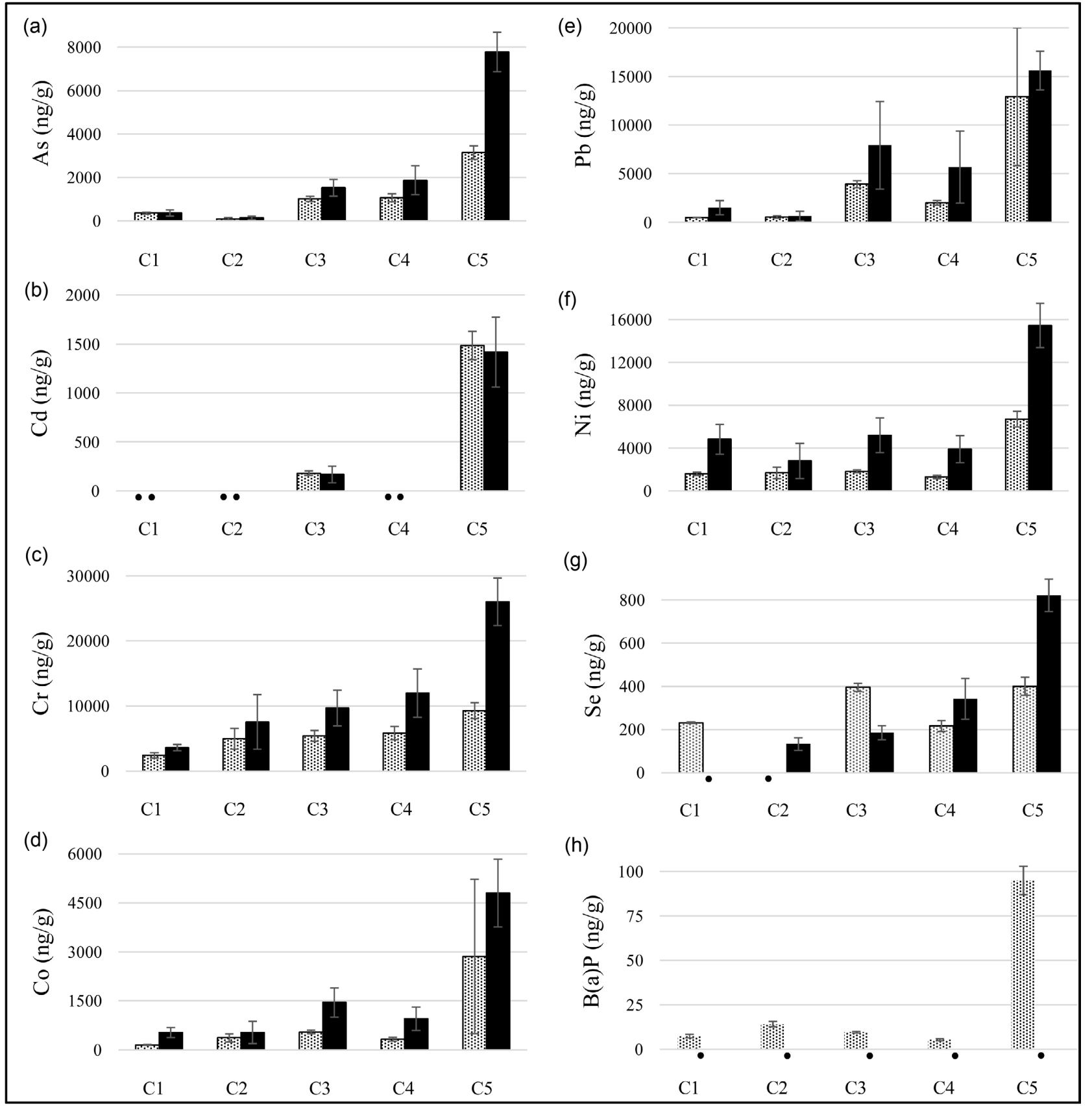

Figure 3. Comparison of trace metals and $\mathrm{B}[\mathrm{a}] \mathrm{P}$ in unburned (gray bars) and burned (black bars) WP charcoal solid waste. (•) means below the limit of quantification. LOQ for As $(0.1 \mu \mathrm{g} / \mathrm{L}), \mathrm{Cd}(0.1 \mu \mathrm{g} / \mathrm{L}), \mathrm{Cr}(1 \mu \mathrm{g} / \mathrm{L}), \mathrm{Co}(0.1 \mu \mathrm{g} / \mathrm{L}), \mathrm{Pb}(0.1 \mu \mathrm{g} / \mathrm{L}), \mathrm{Ni}(0.1$ $\mu \mathrm{g} / \mathrm{L})$, Se $(0.5 \mu \mathrm{g} / \mathrm{L}), \mathrm{B}[\mathrm{a}] \mathrm{P}(0.5 \mathrm{ng} / \mathrm{g})$.

A WP is often coated with a layer of metallic paint for aesthetic purposes, so coating substances may be depleted and introduced into the charcoal sample during the burning process. However, a more plausible explanation is that all tobacco and charcoal samples experience a mass loss due to heating (volatilization or combustion). Under these temperature conditions, it can be assumed that trace metals are nonvolatile; they most likely remain in the heated products. The decrease in total product mass yielded an apparent increase in metal con- 
centrations (except As in brands T4 [passion fruit] and T5 [blueberry and mint]).

Table 3 shows the comparison between trace metal yield range results of different tobacco product solid waste (i.e., WP tobacco, little cigar, cigarette, smokeless, WP charcoal). The yield results from the WP tobacco brand T9 (nicotine gel) were excluded due to the absence of tobacco leaves. Interestingly, all our metals except for Ni in WP tobacco were shown to have higher concentration ranges (before heating) than observed by Saadawi et al. [77]. This difference may be due to the variability in the non-tobacco ingredients in the WP tobacco mixture. Tobacco molasses is a common non-tobacco ingredient used to manufacture WP tobacco mixtures and has been shown to contain high concentrations of trace metals [78] [79] [80]. Generally, metal concentration ranges in WP tobacco before heating appears lower than those reported for the little cigar, cigarette, and smokeless tobacco product solid waste [77] [81] [82] [83] [84] [85], which are not unexpected as flavored WP tobacco mixture is composed of approx. 30\% tobacco and 70\% non-tobacco ingredients [19].

Table 3. Comparison of metal concentration ranges in various tobacco product solid waste.

\begin{tabular}{|c|c|c|c|c|c|c|c|c|}
\hline Product Type & & ${ }^{\mathrm{a}}$ As & ${ }^{\mathrm{a}} \mathrm{Cd}$ & ${ }^{\mathrm{a}} \mathrm{Cr}$ & ${ }^{\mathrm{a}} \mathrm{Co}$ & ${ }^{\mathrm{a}} \mathrm{Pb}$ & ${ }^{\mathrm{a}} \mathrm{Ni}$ & ${ }^{\mathrm{a}} \mathrm{Se}$ \\
\hline \multicolumn{9}{|c|}{ Tobacco } \\
\hline \multirow{2}{*}{$\begin{array}{l}\text { WP Tobacco } \\
\text { (our results) }\end{array}$} & $\mathrm{BH}$ & $40-114$ & $87-285$ & $732-1581$ & $<0.1-61$ & $<0.1-227$ & $213-464$ & $<0.5-443$ \\
\hline & $\mathrm{AH}$ & $<0.1-192$ & $203-788$ & $728-2657$ & $48-119$ & $77-466$ & $384-875$ & $<0.5-624$ \\
\hline \multirow{2}{*}{ WP Tobacco [77] } & $\mathrm{BH}$ & $10-40$ & $100-270$ & $150-370$ & & $<1-70$ & $140-640$ & $2-14$ \\
\hline & $\mathrm{AH}$ & & & & & & & \\
\hline \multirow{2}{*}{ Little Cigar [81] } & $\mathrm{BH}$ & $120-660$ & $752-1740$ & $880-6460$ & $650-1000$ & $460-1230$ & $1500-4370$ & $90-369$ \\
\hline & $\mathrm{AH}$ & & & & & & & \\
\hline \multirow{2}{*}{ Cigarette [82] } & $\mathrm{BH}$ & $250-1070$ & $20-50$ & $30-1580$ & & $600-7930$ & $370-1180$ & $180-340$ \\
\hline & $\mathrm{AH}$ & & & & & & & \\
\hline \multirow{2}{*}{ Cigarette [83] } & $\mathrm{BH}$ & & $243-795$ & & $1233-4066$ & $2500-27,330$ & & \\
\hline & $\mathrm{AH}$ & & & & & & & \\
\hline \multirow{2}{*}{ Smokeless [84] } & $\mathrm{BH}$ & & $10-170$ & $2770-11,400$ & $10-30$ & $0-2480$ & $20-70$ & \\
\hline & $\mathrm{AH}$ & & & & & & & \\
\hline \multirow{2}{*}{ Smokeless [85] } & $\mathrm{BH}$ & & $1750-1950$ & $15020-16,380$ & & $1560-1700$ & $1380-1770$ & \\
\hline & $\mathrm{AH}$ & & & & & & & \\
\hline \multicolumn{9}{|c|}{ Charcoal } \\
\hline \multirow{2}{*}{$\begin{array}{l}\text { WP Charcoal } \\
\text { (our results) }\end{array}$} & $\mathrm{BB}$ & $91-3147$ & $<0.1-1485$ & $2399-9287$ & $153-2857$ & $498-12,922$ & $1298-6699$ & $<0.5-400$ \\
\hline & $\mathrm{AB}$ & $356-7779$ & $<0.1-1417$ & $3609-26,029$ & $530-4799$ & $638-15,621$ & $2800-15,440$ & $<0.5-821$ \\
\hline \multirow{2}{*}{ WP Charcoal [76] } & $\mathrm{BB}$ & & $110-1530$ & $2350-2520$ & & $2820-9090$ & & \\
\hline & $\mathrm{AB}$ & & & & & & & \\
\hline \multirow{2}{*}{ WP Charcoal [31] } & BB & $15-10,300$ & $3-2100$ & $161-8320$ & $124-10,000$ & $95-55,600$ & $274-14,000$ & \\
\hline & $\mathrm{AB}$ & $377-57,200$ & $2-3360$ & $7380-142,000$ & $1180-24,600$ & $2440-81,200$ & $6070-204,000$ & $366-3330$ \\
\hline
\end{tabular}

Note. ${ }^{a} \mathrm{As}, \mathrm{Cd}, \mathrm{Cr}, \mathrm{Co}, \mathrm{Pb}, \mathrm{Ni}$, Se all values are presented in ng/g; BH (before heating); AH (after heating); $\mathrm{BB}$ (before burning); $\mathrm{AB}$ (after burning). 
Currently, the trace metal yield results generated under heating conditions in other tobacco product solid waste (tobacco-derived) are limited in the literature, making the comparison of metal concentration ranges relatively challenging. This may be worth exploring in the future, particularly with solid waste from heated tobacco products (HTPs). Our metal concentration ranges in WP charcoal before burning were in the same order of magnitude as those reported by others [76] [31]. However, it appeared that a greater enhancement of metal concentrations after burning in WP charcoal solid waste was observed by Saadawi et al. [31], which suggests that there may be other factors contributing to the metal yields during the combustion process; these other factors may include the WP apparatus materials (e.g., WP head, metallic coating, aluminum foil), as they all had direct contact with the WP charcoal solid waste during the burning process.

Figure 3(h) shows that $\mathrm{B}[\mathrm{a}] \mathrm{P}$ was not detected in all WP charcoal samples after heating but was detected before heating $(7.3,14.1,9.5,5.4$, and $95 \mathrm{ng} / \mathrm{g}$ for $\mathrm{C} 1, \mathrm{C} 2, \mathrm{C} 3, \mathrm{C} 4, \mathrm{C} 5$, respectively). The results of $\mathrm{B}[\mathrm{a}] \mathrm{P}$ concentrations (before heating) are in good agreement with $\mathrm{B}[\mathrm{a}] \mathrm{P}$ concentrations found in raw WP charcoal by others [48] [86], which suggests that $\mathrm{B}[\mathrm{a}] \mathrm{P}$ is likely transferred to the tobacco smoke during the WP smoking session. WP charcoal brand C5 (natural and finger shape) contains substantially higher quantities of heavy metals and $\mathrm{B}[\mathrm{a}] \mathrm{P}$ compared to other brands investigated, and this result shows that the labeling of WP charcoal could be misleading (ie, natural) and potentially give consumers a false sense of security when using WP tobacco products.

\section{Conclusion}

In this study, the concentrations of selected HPHCs (acrolein, benzene, isoprene, catechol, phenol, FA, B[a]P, NNN, and NNK) and selected trace elements (As, $\mathrm{Cd}, \mathrm{Cr}, \mathrm{Pb}, \mathrm{Se}, \mathrm{Co}, \mathrm{Ni}$ ) were investigated in ten $\mathrm{WP}$ tobacco products with flavors and five WP charcoal products with different materials and shapes. No noticeable trend is observed among the WP tobacco flavors. However, WP charcoal brand C5 (natural and finger shape) contained substantially higher quantities of heavy metals and $\mathrm{B}[\mathrm{a}] \mathrm{P}$ than other brands investigated. This study demonstrates that trace metal residues are present in unheated and unburned WP tobacco and charcoal and are present at higher concentrations after consumer use and thus could have an environmental impact. Results indicate that $\mathrm{Cr}, \mathrm{Pb}$, and $\mathrm{Ni}$ are the most abundant metals in most WP charcoal brands we investigated. We also demonstrated that WP tobacco and WP charcoal products contained substantial quantities of $\mathrm{B}[\mathrm{a}] \mathrm{P}$ before heating or burning, but $\mathrm{B}[\mathrm{a}] \mathrm{P}$ was not detected in the spent charcoal after consumption. This study characterizes the environmental harms of burned WP tobacco and charcoal products and their potential impact on environmental health. Based on the current data and use patterns, the environmental impact for WP may seem small. However, more studies are needed to estimate the magnitude of the environmental impact of WP tobacco use. 


\section{Acknowledgements}

The authors would like to thank Battelle Memorial Institute, Katherine S. Lovejoy, Sarah (Vichensont) Amyot, Jeffrey R. Ammann, Delshanee Kotandeniya, Jeannie H. Jeong-Im of the Food and Drug Administration, Center for Tobacco Products, and Marielle C. Brinkman for their collegial input on this project. The research was funded by FDA contract HHSF223201610607A. Battelle Memorial Institute (Columbus, Ohio, USA) performed all the experiments from September 15,2016 to July 20, 2018. The findings and conclusions in this report are those of the authors and do not necessarily represent the official position of the Food and Drug Administration.

\section{Conflicts of Interest}

The authors do not have any potential conflict of interests or competing interests to declare.

\section{References}

[1] Primack, B.A., Shensa A., Kim K.H., Carroll M.V., Hoban M.T., Leino E.V., et al. (2012) Waterpipe Smoking among U.S. University Students. Nicotine \& Tobacco Research, 15, 29-35. https://doi.org/10.1093/ntr/nts076

[2] Aljarrah, K., Ababneh, Z.Q. and Al-Delaimy, W.K. (2009) Perceptions of Hookah Smoking Harmfulness: Predictors and Characteristics among Current Hookah Users. Tobacco Induced Diseases, 5, Article No. 16. https://doi.org/10.1186/1617-9625-5-16

[3] Pärna, K., Usin, J. and Ringmets, I. (2008) Cigarette and Waterpipe Smoking among Adolescents in Estonia: Hbsc Survey Results, 1994-2006. BMC Public Health, 8, Article No. 392. https://doi.org/10.1186/1471-2458-8-392

[4] Primack, B.A., Walsh, M., Bryce, C. and Eissenberg, T. (2009) Water-Pipe Tobacco Smoking among Middle and High School Students in Arizona. Pediatrics, 123, e282-e288. https://doi.org/10.1542/peds.2008-1663

[5] Jawad, M., Charide, R., Waziry, R., Darzi, A., Ballout, R.A. and Akl, E.A. (2018) The Prevalence and Trends of Waterpipe Tobacco Smoking: A Systematic Review. PLoS $O N E$, 13, Article ID: e0192191. https://doi.org/10.1371/journal.pone.0192191

[6] Akl, E.A., Jawad, M., Lam, W.Y., Co, C.N., Obeid, R. and Irani, J. (2013) Motives, Beliefs and Attitudes towards Waterpipe Tobacco Smoking: A Systematic Review. Harm Reduction Journal, 10, Article No. 12. https://doi.org/10.1186/1477-7517-10-12

[7] World Health Organization (2005) Tobreg Advisory Note: Waterpipe Tobacco Smoking: Health Effects. Research Needs and Recommended Actions by Regulators. World Health Organization.

[8] Shihadeh, A., Azar, S., Antonios, C. and Haddad, A. (2004) Towards a Topographical Model of Narghile Water-Pipe Café Smoking: A Pilot Study in a High Socioeconomic Status Neighborhood of Beirut, Lebanon. Pharmacology Biochemistry and Behavior, 79, 75-82. https://doi.org/10.1016/j.pbb.2004.06.005

[9] Katurji, M., Daher, N., Sheheitli, H., Saleh, R. and Shihadeh, A. (2010) Direct Measurement of Toxicants Inhaled by Water Pipe Users in the Natural Environment Using a Real-Time in Situ Sampling Technique. Inhalation Toxicology, 22, 1101-1109. 
https://doi.org/10.3109/08958378.2010.524265

[10] Sepetdjian, E., Shihadeh, A. and Saliba, N.A. (2008) Measurement of 16 Polycyclic Aromatic Hydrocarbons in Narghile Waterpipe Tobacco Smoke. Food and Chemical Toxicology, 46, 1582-1590. https://doi.org/10.1016/j.fct.2007.12.028

[11] FDA (Food and Drug Administration) (2010) Regulations Restricting the Sale and Distribution of Cigarettes and Smokeless Tobacco to Protect Children and Adolescents. Final Rule. Federal Register, 75, 13225-13232.

[12] FDA (Food and Drug Administration) (2016) Deeming Tobacco Products to Be Subject to the Federal Food, Drug, and Cosmetic Act, as Amended by the Family Smoking Prevention and Tobacco Control Act; Restrictions on the Sale and Distribution of Tobacco Products and Required Warning Statements for Tobacco Products. Federal Register, 81, 28973-29106.

[13] Shihadeh, A. (2003) Investigation of Mainstream Smoke Aerosol of the Argileh Water Pipe. Food and Chemical Toxicology, 41, 143-152.

https://doi.org/10.1016/S0278-6915(02)00220-X

[14] Retzky, S.S., Spiller, H.A. and Callahan-Lyon, P. (2018) Calls to Poison Centers for Hookah Smoking Exposures. Clinical Toxicology, 56, 442-445.

https://doi.org/10.1080/15563650.2017.1400556

[15] Hammal, F., Wild, T.C., Nykiforuk, C., Abdullahi, K., Mussie, D. and Finegan, B.A. (2015) Waterpipe (Hookah) Smoking among Youth and Women in Canada Is New, Not Traditional. Nicotine \& Tobacco Research, 18, 757-762. https://doi.org/10.1093/ntr/ntv152

[16] Martinasek, M.P., McDermott, R.J. and Martini, L. (2011) Waterpipe (Hookah) Tobacco Smoking among Youth. Current Problems in Pediatric and Adolescent Health Care, 41, 34-57. https://doi.org/10.1016/j.cppeds.2010.10.001

[17] Al-Kazwini, A.T., Said, A.J. and Sdepanian, S. (2015) Compartmental Analysis of Metals in Waterpipe Smoking Technique.BMC Public Health, 15, Article No. 153.

https://doi.org/10.1186/s12889-015-1373-6

[18] Chaouachi, K. (2009) Hookah (Shisha, Narghile) Smoking and Environmental Tobacco Smoke (ETS). A Critical Review of the Relevant Literature and the Public Health Consequences. International Journal of Environmental Research and Public Health, 6, 798-843. https://doi.org/10.3390/ijerph6020798

[19] Schubert, J., Luch, A. and Schulz, T.G. (2013) Waterpipe Smoking: Analysis of the Aroma Profile of Flavored Waterpipe Tobaccos. Talanta, 115, 665-674. https://doi.org/10.1016/j.talanta.2013.06.022

[20] Maziak, W., Eissenberg, T., Rastam, S., Hammal, F., Asfar, T., Bachir, M.E., et al. (2004) Beliefs and Attitudes Related to Narghile (Waterpipe) Smoking among University Students in Syria. Annals of Epidemiology, 14, 646-654. https://doi.org/10.1016/j.annepidem.2003.11.003

[21] El-Zaatari, Z.M., Chami, H.A. and Zaatari, G.S. (2015) Health Effects Associated with Waterpipe Smoking. Tobacco Control, 24, i31-i43. https://doi.org/10.1136/tobaccocontrol-2014-051908

[22] Waziry, R., Jawad, M., Ballout, R.A., Al Akel, M. and Akl, E.A. (2017) The Effects of Waterpipe Tobacco Smoking on Health Outcomes: An Updated Systematic Review and Meta-Analysis. International Journal of Epidemiology, 46, 32-43. https://doi.org/10.1093/ije/dyw021

[23] Jaishankar, M., Tseten, T., Anbalagan, N., Mathew, B.B. and Beeregowda, K.N. (2014) Toxicity, Mechanism and Health Effects of Some Heavy Metals. Interdisciplinary Toxicology, 7, 60-72. https://doi.org/10.2478/intox-2014-0009 
[24] Golia, E.E., Dimirkou, A. and Mitsios, I.K. (2009) Heavy-Metal Concentration in Tobacco Leaves in Relation to Their Available Soil Fractions. Communications in Soil Science and Plant Analysis, 40, 106-120. https://doi.org/10.1080/00103620802623570

[25] Stephens, W.E., Calder, A. and Newton, J. (2005) Source and Health Implications of High Toxic Metal Concentrations in Illicit Tobacco Products. Environmental Science \& Technology, 39, 479-488. https://doi.org/10.1021/es049038s

[26] Bacha, Z.A., Salameh, P. and Waked, M. (2007) Saliva Cotinine and Exhaled Carbon Monoxide Levels in Natural Environment Waterpipe Smokers. Inhalation Toxicology, 19, 771-777. https://doi.org/10.1080/08958370701401699

[27] Senneca, O., Ciaravolo, S. and Nunziata, A. (2007) Composition of the Gaseous Products of Pyrolysis of Tobacco under Inert and Oxidative Conditions. Journal of Analytical and Applied Pyrolysis, 79, 234-243.

https://doi.org/10.1016/j.jaap.2006.09.011

[28] Uchiyama, S., Noguchi, M., Sato, A., Ishitsuka, M., Inaba, Y. and Kunugita, N. (2020) Determination of Thermal Decomposition Products Generated from E-Cigarettes. Chemical Research in Toxicology, 33, 576-583.

https://doi.org/10.1021/acs.chemrestox.9b00410

[29] Torikai, K., Yoshida, S. and Takahashi, H. (2004) Effects of Temperature, Atmosphere and $\mathrm{Ph}$ on the Generation of Smoke Compounds during Tobacco Pyrolysis.Food and Chemical Toxicology, 42, 1409-1417. https://doi.org/10.1016/j.fct.2004.04.002

[30] McGrath, T.E., Wooten, J.B., Chan, G.W. and Hajaligol, M.R. (2007) Formation of Polycyclic Aromatic Hydrocarbons from Tobacco: The Link between Low Temperature Residual Solid (Char) and Pah Formation. Food and Chemical Toxicology, 45, 1039-1050. https://doi.org/10.1016/j.fct.2006.12.010

[31] Saadawi, R., Hachmoeller, O., Winfough, M., Hanley, T., Caruso, J.A. and Landero Figueroa, J.A. (2014) The Hookah Series Part 2: Elemental Analysis and Arsenic Speciation in Hookah Charcoals. Journal of Analytical Atomic Spectrometry, 29, 2146-2158. https://doi.org/10.1039/C4JA00163J

[32] Pulford, I.D. and Watson, C. (2003) Phytoremediation of Heavy Metal-Contaminated Land by Trees-A Review. Environment International, 29, 529-540.

https://doi.org/10.1016/S0160-4120(02)00152-6

[33] Novotny, E.T., Lum, K., Smith, E., Wang, V. and Barnes, R. (2009) Cigarettes Butts and the Case for an Environmental Policy on Hazardous Cigarette Waste. International Journal of Environmental Research and Public Health, 6, 1691-1705. https://doi.org/10.3390/ijerph6051691

[34] Smith, E.A. and Novotny, T.E. (2011) Whose Butt Is It? Tobacco Industry Research About Smokers and Cigarette Butt Waste. Tobacco Control, 20, i2-i9.

https://doi.org/10.1136/tc.2010.040105

[35] Baran, W., Madej-Knysak, D., Sobczak, A. and Adamek, E. (2020) The Influence of Waste from Electronic Cigarettes, Conventional Cigarettes and Heat-Not-Burn Tobacco Products on Microorganisms. Journal of Hazardous Materials, 385, Article ID: 121591. https://doi.org/10.1016/j.jhazmat.2019.121591

[36] Venugopal, P.D., Hanna, S.K., Gagliano, G.G. and Chang, H.W. (2021) No Butts on the Beach: Aquatic Toxicity of Cigarette Butt Leachate Chemicals. Tobacco Regulatory Science, 7, 17-30. https://doi.org/10.18001/TRS.7.1.2

[37] Hoek, J., Gendall, P., Blank, M.-L., Robertson, L. and Marsh, L. (2020) Butting Out: An Analysis of Support for Measures to Address Tobacco Product Waste. Tobacco 
Control, 29, 131-137. https://doi.org/10.1136/tobaccocontrol-2019-054956

[38] Brinkman, M.C., Kim, H., Gordon, S.M., Kroeger, R.R., Reyes, I.L., Deojay, D.M., et al. (2016) Design and Validation of a Research-Grade Waterpipe Equipped with Puff Topography Analyzer. Nicotine \& Tobacco Research, 18, 785-793. https://doi.org/10.1093/ntr/ntv180

[39] El Hourani, M., Talih, S., Salman, R., Karaoghlanian, N., Karam, E., El Hage, R., et al. (2019) Comparison of Co, Pah, Nicotine, and Aldehyde Emissions in Waterpipe Tobacco Smoke Generated Using Electrical and Charcoal Heating Methods. Chemical Research in Toxicology, 32, 1235-1240.

https://doi.org/10.1021/acs.chemrestox.9b00045

[40] Edwards, R.L., Moore, R., Alrefai-Kirkpatrick, R. and Amyot, S.A. (2020) Testing of a Commercial Waterpipe Electric Heater and a Research-Grade Waterpipe Electric Heater. Tobacco Prevention \& Cessation, 6, Article No. 49. https://doi.org/10.18332/tpc/125355

[41] EPA (U.S. Environmental Protection Agency) (2003) Method 5030c: Purge-and-Trap for Aqueous Samples. U.S. Environmental Protection Agency.

[42] EPA (U.S. Environmental Protection Agency) (2002) Method 5035a: Closed-System Purge-and-Trap and Extraction for Volatile Organics in Soil and Waste Samples. U.S. Environmental Protection Agency.

[43] EPA (U.S. Environmental Protection Agency) (2006) Method 8260c: Determination of Semivolatile Organic Compounds by Gas Chromatography/Mass Spectrometry. U.S. Environmental Protection Agency.

[44] Uhler, R.M., Healey, E.M., McCarthy, K.J., Uhler, A.D. and Stout, S.A. (2003) Molecular Fingerprinting of Gasoline by a Modified Epa 8260 Gas Chromatography-Mass Spectrometry Method. International Journal of Environmental Analytical Chemistry, 83, 1-20. https://doi.org/10.1080/0306731031000104218

[45] EPA (U.S. Environmental Protection Agency) (1996) Method 8315a: Determination of Carbonyl Compounds by High Performance Liquid Chromatography (Hplc). U.S. Environmental Protection Agency.

[46] EPA (U.S. Environmental Protection Agency) (1999) Method to-11a: Determination of Formaldehyde in Ambient Air Using Adsorbent Cartridge Followed by High Performance Liquid Chromatography (Hplc). U.S. Environmental Protection Agency.

[47] Al Rashidi, M., Shihadeh, A. and Saliba, N.A. (2008) Volatile Aldehydes in the Mainstream Smoke of the Narghile Waterpipe. Food and Chemical Toxicology, 46, 3546-3549. https://doi.org/10.1016/j.fct.2008.09.007

[48] Sepetdjian, E., Saliba, N. and Shihadeh, A. (2010) Carcinogenic Pah in Waterpipe Charcoal Products. Food and Chemical Toxicology, 48, 3242-3245.

https://doi.org/10.1016/j.fct.2010.08.033

[49] EPA (U.S. Environmental Protection Agency) (2014) Method 8000d: Determinative Chromatographic Separations. U.S. Environmental Protection Agency.

[50] EPA (U.S. Environmental Protection Agency) (1994) Method 1613: Tetra- through Octa-Chlorinated Dioxins and Furans by Isotope Dilution Hrgc/Hrms. U.S. Environmental Protection Agency.

[51] Lawler, T.S., Stanfill, S.B., Zhang, L., Ashley, D.L. and Watson, C.H. (2013) Chemical Characterization of Domestic Oral Tobacco Products: Total Nicotine, pH, Unprotonated Nicotine and Tobacco-Specific $N$-Nitrosamines. Food and Chemical Toxicology, 57, 380-386. https://doi.org/10.1016/j.fct.2013.03.011

[52] EPA (U.S. Environmental Protection Agency) (2014) Method 8270d: Semivolatile Organic Compounds by Gas Chromatography/Mass Spectrometry. U.S. Environ- 
mental Protection Agency.

[53] Schubert, J., Müller, F.D., Schmidt, R., Luch, A. and Schulz, T.G. (2015) Waterpipe Smoke: Source of Toxic and Carcinogenic Vocs, Phenols and Heavy Metals? Archives of Toxicology, 89, 2129-2139. https://doi.org/10.1007/s00204-014-1372-x

[54] EPA (U.S. Environmental Protection Agency) (1994) Method 200.8: Determination of Trace Elements in Waters and Wastes by Inductively Coupled Plasma-Mass Spectrometry. U.S. Environmental Protection Agency.

[55] EPA (U.S. Environmental Protection Agency) (1998) Method 6020a: Inductively Coupled Plasma-Mass Spectrometry. U.S. Environmental Protection Agency.

[56] Brown, B.G., Borschke, A.J. and Doolittle, D.J. (2003) An Analysis of the Role of Tobacco-Specific Nitrosamines in the Carcinogenicity of Tobacco Smoke. Nonlinearity in Biology, Toxicology and Medicine, 1, 179-198. https://doi.org/10.1080/15401420391434324

[57] Novotny, T.E. and Slaughter, E. (2014) Tobacco Product Easte: An Environmental Approach to Reduce Tobacco Consumption. Current Environmental Health Reports, 1, 208-216. https://doi.org/10.1007/s40572-014-0016-X

[58] Smith, E.A. and McDaniel, P.A. (2011) Covering Their Butts: Responses to the Cigarette Litter Problem. Tobacco Control, 20, 100-106. https://doi.org/10.1136/tc.2010.036491

[59] Pepper, J.K. and Eissenberg, T. (2014) Waterpipes and Electronic Cigarettes: Increasing Prevalence and Expanding Science. Chemical Research in Toxicology, 27, 1336-1343. https://doi.org/10.1021/tx500200j

[60] Talhout, R., Opperhuizen, A. and van Amsterdam, J.G.C. (2006) Sugars as Tobacco Ingredient: Effects on Mainstream Smoke Composition. Food and Chemical Toxicology, 44, 1789-1798. https://doi.org/10.1016/j.fct.2006.06.016

[61] Apsley, A., Galea, K.S., Sánchez-Jiménez, A., Semple, S., Wareing, H., van Tongeren, M., et al. (2011) Assessment of Polycyclic Aromatic Hydrocarbons, Carbon Monoxide, Nicotine, Metal Contents and Particle Size Distribution of Mainstream Shisha Smoke. Journal of Environmental Health Research, 11, 93-104.

[62] Babich, H. and Davis, D.L. (1981) Phenol: A Review of Environmental and Health Risks. Regulatory Toxicology and Pharmacology, 1, 90-109. https://doi.org/10.1016/0273-2300(81)90071-4

[63] Kitchens, J.F., Casner, R., Edwards, G., Harward, W. and Macri, B. (1976) Investigation of Selected Potential Environmental Contaminants: Formaldehyde. U.S. Environmental Protection Agency.

[64] Harkov, R. and Greenberg, A. (1985) Benzo(a)Pyrene in New Jersey-Results from a Twenty-Seven-Site Study. Journal of the Air Pollution Control Association, 35, 238-243. https://doi.org/10.1080/00022470.1985.10465906

[65] Wu, J.-P., Li, M.-H., Chen, J.-S. and Lee, H.-L. (2012) In Vivo and in Vitro Metabolism of Tobacco-Specific Nitrosamine, 4-(Methylnitrosamino)-1-(3-Pyridyl)-1-Butanone (Nnk), by the Freshwater Planarian, Dugesia japonica. Chemosphere, 87, 1341-1347. https://doi.org/10.1016/j.chemosphere.2012.02.024

[66] Andra, S.S. and Makris, K.C. (2011) Tobacco-Specific Nitrosamines in Water: An Unexplored Environmental Health Risk. Environment International, 37, 412-417. https://doi.org/10.1016/j.envint.2010.11.003

[67] Rainey, C., Shifflett, J., Goodpaster, J. and Bezabeh, D. (2013) Quantitative Analysis of Humectants in Tobacco Products Using Gas Chromatography (GC) with Simultaneous Mass Spectrometry (MSD) and Flame Ionization Detection (FID). Beitrage 
zur Tabakforschung International, 25, 576-585.

https://doi.org/10.2478/cttr-2013-0934

[68] Schubert, J., Heinke, V., Bewersdorff, J., Luch, A. and Schulz, T.G. (2012) Waterpipe Smoking: The Role of Humectants in the Release of Toxic Carbonyls. Archives of Toxicology, 86, 1309-1316. https://doi.org/10.1007/s00204-012-0884-5

[69] Işikver, Y. and T. Ecevit (2016) Preparation and Characterization of Nicotine-Selective Hydrogels. Polymer Engineering \& Science, 56, 1004-1011. https://doi.org/10.1002/pen.24330

[70] Stanfill, S.B., Jia, L.T., Ashley, D.L. and Watson, C.H. (2009) Rapid and Chemically Selective Nicotine Quantification in Smokeless Tobacco Products Using GC-MS. Journal of Chromatographic Science, 47, 902-909.

https://doi.org/10.1093/chromsci/47.10.902

[71] Andersen, R.A., Fleming, P.D., Hamilton-Kemp, T.R. and Hildebrand, D.F. (1993) $\mathrm{pH}$ Changes in Smokeless Tobaccos Undergoing Nitrosation during Prolonged Storage: Effects of Moisture, Temperature, and Duration. Journal of Agricultural and Food Chemistry, 41, 968-972. https://doi.org/10.1021/jf00030a026

[72] Djordjevic, M.V., Hoffmann, D., Glynn, T. and Connolly, G.N. (1995) Us Commercial Brands of Moist Snuff, 1994-Assessment of Nicotine, Moisture, and Ph. Tobacco Control, 4, 62-66. https://doi.org/10.1021/jf00030a026

[73] Chuan, M.C., Shu, G.Y. and Liu, J.C. (1996) Solubility of Heavy Metals in a Contaminated Soil: Effects of Redox Potential and Ph. Water, Air, \& Soil Pollution, 90, 543-556. https://doi.org/10.1007/BF00282668

[74] Wuana, R.A. and Okieimen, F.E. (2011) Heavy Metals in Contaminated Soils: A Review of Sources, Chemistry, Risks and Best Available Strategies for Remediation. International Scholarly Research Notices, 2011, Article ID: 402647. https://doi.org/10.5402/2011/402647

[75] Tchounwou, P.B., Yedjou, C.G., Patlolla, A.K. and Sutton, D.J. (2012) Heavy Metal Toxicity and the Environment. In: Luch, A., Ed., Molecular, Clinical and Environmental Toxicology, Vol. 101, Springer, Basel, 133-164.

https://doi.org/10.1007/978-3-7643-8340-4_6

[76] Elsayed, Y., Dalibalta, S. and Abu-Farha, N. (2016) Chemical Analysis and Potential Health Risks of Hookah Charcoal. Science of the Total Environment, 569-570, 262-268. https://doi.org/10.1016/j.scitotenv.2016.06.108

[77] Saadawi, R., Landero Figueroa, J.A., Hanley, T. and Caruso, J. (2012) The Hookah Series Part 1: Total Metal Analysis in Hookah Tobacco (Narghile, Shisha) - An Initial Study. Analytical Methods, 4, 3604-3611. https://doi.org/10.1039/c2ay26065d

[78] Alsaffar, N.M. (2016) Assessment of Toxic Levels of Toxic Heavy-Metals. Contaminants in Marketed Molasses (Tobacco) at Baghdad. Journal of the Indian Society of Toxicology, 12, 13-19.

[79] Talio, M.C., Alesso, M., Acosta, M., Wills, V.S. and Fernández, L.P. (2017) Sequential Determination of Nickel and Cadmium in Tobacco, Molasses and Refill Solutions for E-Cigarettes Samples by Molecular Fluorescence. Talanta, 174, 221-227. https://doi.org/10.1016/j.talanta.2017.06.015

[80] Abdel-Rahman, G.N., Nassar, N.R., Heikal, Y.A., Abou-Donia, M.A., Naguib, M.M. and Fadel, M. (2016) Effect of Different Treatments on Heavy Metal Concentration in Sugar Cane Molasses. International Journal of Agriculture and Biology, 10, 43-48.

[81] Pappas, R.S., Martone, N., Gonzalez-Jimenez, N., Fresquez, M.R. and Watson, C.H. (2015) Determination of Toxic Metals in Little Cigar Tobacco with "Triple Quad" ICP-MS. Journal of Analytical Toxicology, 39, 347-352. 
https://doi.org/10.1093/jat/bkv016

[82] Swami, K., Judd, C.D. and Orsini, J. (2009) Trace Metals Analysis of Legal and Counterfeit Cigarette Tobacco Samples Using Inductively Coupled Plasma Mass Spectrometry and Cold Vapor Atomic Absorption Spectrometry. Spectroscopy Letters, 42, 479-490. https://doi.org/10.1080/00387010903267799

[83] Ajab, H., Yasmeen, S., Yaqub, A., Ajab, Z., Junaid, M., Siddique, M., et al. (2008) Evaluation of Trace Metals in Tobacco of Local and Imported Cigarette Brands Used in Pakistan by Spectrophotometer through Microwave Digestion. Toxicological Sciences, 33, 415-420. https://doi.org/10.2131/jts.33.415

[84] Orisakwe, O.E., Igweze, Z.N., Okolo, K.O. and Ajaezi, G.C. (2014) Heavy Metal Hazards of Nigerian Smokeless Tobacco. Tobacco Control, 23, 513-517. https://doi.org/10.1136/tobaccocontrol-2012-050955

[85] Al-Mukhaini, N., Ba-Omar, T., Eltayeb, E. and Al-Shehi, A. (2014) Determination of Heavy Metals in the Common Smokeless Tobacco Afzal in Oman. Sultan Qaboos University Medical Journal, 14, e349-e355.

[86] Nguyen, T., Hlangothi, D., Martinez, 3rd, R.A., Jacob, D., Anthony, K., Nance, H., et al. (2013) Charcoal Burning as a Source of Polyaromatic Hydrocarbons in Waterpipe Smoking. Journal of Environmental Science and Health, Part B, 48, 1097-102. https://doi.org/10.1080/03601234.2013.824300

[87] CDC (Centers for Disease Control and Prevention ) (1999) Notice Regarding Requirement for Annual Submission of the Quantity of Nicotine Contained in Smokeless Tobacco Products Manufactured, Imported, or Packaged in the United States. Federal Register, 64, 14085-14096. 


\section{Supplementary}

Table S1. Comparison of recovered WP tobacco and WP charcoal solid waste.

\begin{tabular}{cccc}
\hline WP Tobacco Brands & ${ }^{\text {a}}$ Recovery (\%) & WP Charcoal Brands & ${ }^{\text {a Recovery (\%) }}$ \\
\hline T1 Chocolate/Mint & $55.2 \pm 6.1$ & C1 Beech Wood/Disc Shape & $72.5 \pm 0.8$ \\
T2 Blueberry/Mint & $54.4 \pm 5.0$ & C2 Coconut Husks/Cube Shape & $69.6 \pm 3.2$ \\
T3 Orange/Cherry & $47.2 \pm 7.2$ & C3 Instant/Disc Shape & $72.4 \pm 1.6$ \\
T4 Passion Fruit & $50.9 \pm 5.3$ & C4 Quicklight/Disc Shape & $75.7 \pm 1.0$ \\
T5 Blueberry/Mint & $63.5 \pm 7.5$ & C5 Natural/Finger Shape & $58.2 \pm 3.1$ \\
T6 Blueberry/Mint & $53.7 \pm 4.7$ & & \\
T7 Apple & $44.8 \pm 4.1$ & & \\
T8 Peach & $51.6 \pm 3.8$ & & \\
T9 Watermelon & $26.1 \pm 4.3$ & & \\
T10 Orange & $53.1 \pm 8.3$ & & \\
\hline
\end{tabular}

Note. ${ }^{a}$ Recovery (\%) values are presented in $\%$, mean \pm s.d., $\mathrm{N}=7$ per brand.

Table S2. Comparison of $\mathrm{pH}$ and nicotine changes in WP tobacco solid waste.

\begin{tabular}{ccccccc}
\hline WP Tobacco Brands & $\begin{array}{c}{ }^{\mathrm{a}} \text { Unheated } \\
\text { pH }\end{array}$ & $\begin{array}{c}{ }^{\mathrm{a}} \text { Heated } \\
\text { pH }\end{array}$ & $\begin{array}{c}{ }^{\mathrm{b}} \text { Unheated Total } \\
\text { Nicotine }\end{array}$ & $\begin{array}{c}{ }^{\mathrm{b}} \text { Heated Total } \\
\text { Nicotine }\end{array}$ & $\begin{array}{c}{ }^{\mathrm{b}} \text { Unheated Free } \\
\text { Nicotine }\end{array}$ & $\begin{array}{c}{ }^{\mathrm{b}} \text { Heated Free } \\
\text { Nicotine }\end{array}$ \\
\hline T1 Chocolate/Mint & $4.5 \pm 0.0$ & $5.2 \pm 0.1$ & $0.9 \pm 0.0$ & BLOQ & BLOQ & BLOQ \\
T2 Blueberry/Mint & $4.7 \pm 0.0$ & $5.2 \pm 0.0$ & $0.7 \pm 0.0$ & BLOQ & BLOQ & BLOQ \\
T3 Orange/Cherry & $4.4 \pm 0.0$ & $5.0 \pm 0.1$ & $1.5 \pm 0.0$ & $0.8 \pm 0.2$ & BLOQ & BLOQ \\
T4 Passion Fruit & $4.8 \pm 0.0$ & $5.3 \pm 0.1$ & $0.8 \pm 0.2$ & BLOQ & BLOQ & BLOQ \\
T5 Blueberry/Mint & $4.3 \pm 0.0$ & $5.1 \pm 0.2$ & $0.7 \pm 0.0$ & BLOQ & BLOQ & BLOQ \\
T6 Blueberry/Mint & $4.9 \pm 0.0$ & $5.2 \pm 0.1$ & $1.0 \pm 0.0$ & BLOQ & BLOQ & BLOQ \\
T7 Apple & $4.9 \pm 0.0$ & $5.2 \pm 0.1$ & $1.8 \pm 0.0$ & $0.8 \pm 0.2$ & BLOQ & BLOQ \\
T8 Peach & $4.7 \pm 0.0$ & $5.2 \pm 0.1$ & $0.7 \pm 0.0$ & BLOQ & BLOQ & BLOQ \\
T9 Watermelon & $5.2 \pm 0.0$ & $5.6 \pm 0.2$ & BLOQ & BLOQ & BLOQ & BLOQ \\
T10 Orange & $5.3 \pm 0.0$ & $6.2 \pm 0.2$ & $3.1 \pm 0.0$ & $1.0 \pm 0.4$ & BLOQ & BLOQ \\
\hline
\end{tabular}

Note. ${ }^{a}$ Unheated and Heated $\mathrm{pH}$ values are presented in mean \pm s.d., $\mathrm{N}=7$ per brand. ${ }^{b}$ Unheated, Heated, Total or Free Nicotine values are presented in $\mathrm{mg} / \mathrm{g}$ (mean \pm s.d., $\mathrm{N}=7$ per brand). BLOQ means below the limit of quantification and the LOQ for nicotine is $0.5 \mathrm{ng} / \mathrm{g}$.

Table S3. Comparison of humectant in unheated WP tobacco solid waste.

\begin{tabular}{cccc}
\hline WP Tobacco Brands & ${ }^{\mathrm{a} E \text { Ethylene Glycol }}$ & ${ }^{\mathrm{b}}$ Propylene Glycol & ${ }^{\mathrm{c} G l y c e r o l}$ \\
\hline T1 Chocolate/Mint & BLOQ & $33.3 \pm 0.1$ & $377.2 \pm 3.7$ \\
T2 Blueberry/Mint & $0.5 \pm 0.0$ & $6.4 \pm 0.2$ & $386.7 \pm 6.5$ \\
T3 Orange/Cherry & $0.4 \pm 0.0$ & $7.1 \pm 0.2$ & $279.3 \pm 8.1$ \\
T4 Passion Fruit & $0.5 \pm 0.0$ & $16.8 \pm 0.4$ & $381.5 \pm 4.5$ \\
T5 Blueberry/Mint & $1.5 \pm 0.1$ & $87.4 \pm 2.9$ & $384.2 \pm 5.3$ \\
T6 Blueberry/Mint & $1.0 \pm 0.1$ & $37.0 \pm 0.4$ & $378.2 \pm 3.6$ \\
T7 Apple & $0.4 \pm 0.0$ & $13.1 \pm 0.7$ & $226.1 \pm 5.6$ \\
T8 Peach & BLOQ & $21.4 \pm 0.4$ & $370.1 \pm 6.2$ \\
T9 Watermelon & BLOQ & $1.1 \pm 0.0$ & $720.3 \pm 5.7$ \\
T10 Orange & BLOQ & BLOQ & $211.1 \pm 19.2$ \\
\hline
\end{tabular}

Note. ${ }^{a}$ Ethylene Glycol values are presented in $\mathrm{mg} / \mathrm{g}$ (mean \pm s.d., $\mathrm{N}=7$ per brand). BLOQ means below the limit of quantification, LOQ for ethylene glycol $\left(4 \mu \mathrm{g} / \mathrm{g}\right.$ ). ${ }^{\text {b}}$ Propylene Glycol values are presented in $\mathrm{mg} / \mathrm{g}$ (mean \pm s.d., $\mathrm{N}=7$ per brand). BLOQ means below the limit of quantification, LOQ for propylene glycol $(5 \mu \mathrm{g} / \mathrm{g})$. ${ }^{\mathrm{c}} \mathrm{Glycerol}$ values are presented in mg/g (mean $\pm \mathrm{s} . \mathrm{d}$., $\mathrm{N}$ $=7$ per brand). LOQ for glycerol $(0.76 \mathrm{mg} / \mathrm{g})$. 


\section{Supplementary Methods \\ GC-FID Analysis of Nicotine}

Nicotine in WP tobacco samples (1 $\mathrm{g}$ each) was extracted using methyl-tert-butyl ether (MTBE) and isopropanol (IPA) and analyzed using GC (Agilent 6890) with a flame ionization detector (GC-FID) [70] and a fused silica capillary column (DB-WAX 15-m x 0.53-mm ID, $1.0 \mu \mathrm{m}$ film thickness, Agilent 125-7012). Quinoline (CAS 91-22-5, 10 $\mathrm{mg} / \mathrm{mL}$ ) and nicotine (CAS 54-11-5, $50 \mathrm{mg} / \mathrm{mL}$ ) stock solutions were diluted and used as calibration standards. The GC parameters were set as follows: column oven temperature of $65^{\circ} \mathrm{C}$ was held for $2 \mathrm{~min}$, and then ramped to $85^{\circ} \mathrm{C}$ at a rate of $4^{\circ} \mathrm{C} / \mathrm{min}$ and held constant for $2 \mathrm{~min}$. The oven temperature was ramped up again to $230^{\circ} \mathrm{C}$ at a rate of $20^{\circ} \mathrm{C} / \mathrm{min}$ and held constant for another $2 \mathrm{~min}$. The inlet and detector temperatures were set at $230^{\circ} \mathrm{C}$ and $275^{\circ} \mathrm{C}$, respectively. Helium was used as the carrier gas at a column flow rate of $3 \mathrm{~mL} / \mathrm{min}$.

\section{GC-FID Analysis of Humectants}

Glycerol, propylene glycol, and ethylene glycol in unheated and heated WP tobacco samples (4 g of sample each) were extracted into $50 \mathrm{~mL}$ of methanol. $200 \mu \mathrm{L}$ of 1,4-butanediol $(500 \mathrm{mg} / \mathrm{mL})$ was added and used as the internal standard. The extraction solution was shaken for $30 \mathrm{~min}$ on a shaker, and the liquid was decanted into a $50 \mathrm{~mL}$ polypropylene centrifuge tube and centrifuged for $2 \mathrm{~min}$ at $2000 \mathrm{rpm}$. After centrifugation, $1 \mathrm{~mL}$ of extraction solution is filtered through a $0.45 \mu \mathrm{m}$ polytetrafluoroethylene (PTFE) syringe filter into a vial for analysis using GC-FID (Agilent 6890) [68]. The GC parameters were set as follows: column oven temperature of $50^{\circ} \mathrm{C}$ was held for 2 min, and then ramped to $220^{\circ} \mathrm{C}$ at a rate of $30^{\circ} \mathrm{C} / \mathrm{min}$ and held constant for $6 \mathrm{~min}$. The split inlet and detector temperatures were set at $220^{\circ} \mathrm{C}$ and $260^{\circ} \mathrm{C}$, respectively. The split ratio was $20: 1$, and helium was used as the carrier gas at a column flow rate of $1 \mathrm{~mL} / \mathrm{min}$. The column used was SOLGEL-WAX $30 \mathrm{~m} \times 0.25 \mathrm{~mm} \times 0.25 \mu \mathrm{m}$.

\section{Determination of $\mathrm{pH}$ in heated and unheated tobacco}

The $\mathrm{pH}$ of unheated and heated WP tobacco samples was determined using a glass combination electrode and conditions as previously described [87]. Unheated or heated tobacco samples (1 $\mathrm{g}$ of solid sample) were added into a $50 \mathrm{~mL}$ beaker followed by the addition of $10 \mathrm{~mL}$ of distilled water. $\mathrm{pH}$ measurements were acquired at 5,15 , and 30 mins after adding the water. The rearranged Henderson-Hasselbalch equation (Equation (1)) was used to calculate the free-base nicotine quantities:

$$
\text { Nicotine }_{\text {free }}=\frac{\left[10^{\mathrm{pH}-8.02}\right] \text { Nicotine }_{\text {total }}}{1+\left[10^{\mathrm{pH}-8.02}\right]}
$$

